\title{
Article
}

\section{An Unpublished Manuscript of The Teaching of Khety (P. Turin CGT 54019)}

\author{
Judith Jurjens
}

This paper is a publication of P. Turin CGT 54019, which contains an excerpt from The Teaching of Khety, also known as The Satire of the Trades. The papyrus provides a welcome additional source for the second part of the composition (chapters 21-30), particularly because it offers some interesting variants that are unparalleled in the other sources. After a brief introduction on variants in general, including scribal errors, these variants are discussed in detail. The colophon that concludes the papyrus is badly preserved. However, it mentions the mortuary temple of Ramesses III at Medinet Habu. This is quite remarkable, since locations are seldom referred to in the colophons of literary texts. These rare instances are analyzed here to try to reconstruct the manuscript's colophon. Finally, the relationship between literary texts and mortuary temples is discussed to shed light on the social context of P. Turin CGT 54019.

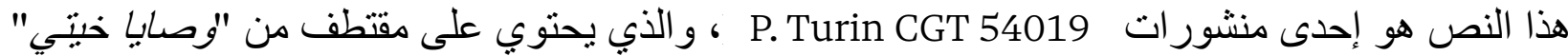

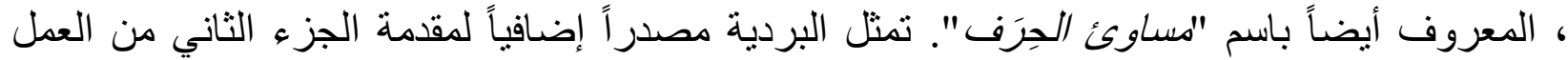

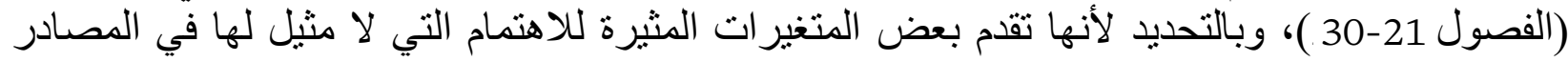

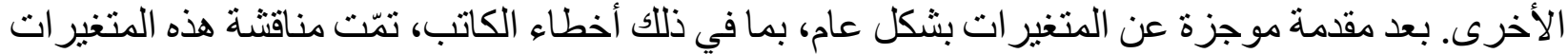

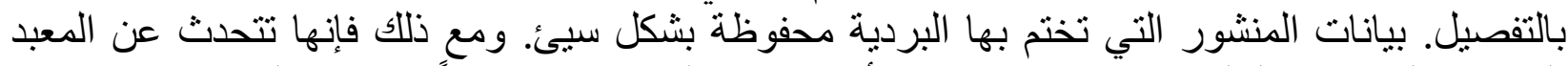

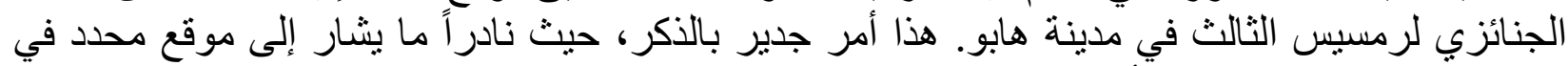
بيانات المنشور للنصوص الأدبية. يتم هنا دراسة وتحليل هذه الحالات النادرة لمحاولة إعادة بناء بياء بيانات

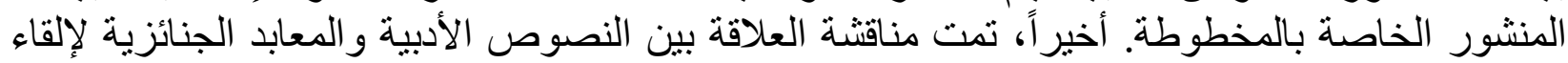
الضوء على المنظومة الاجتماعية لـ P. Turin CGT 54019

\section{The "discovery" of the papyrus}

On 8 September 1978 Alessandro Roccati identified amongst the unpublished papyri in the Museo Egizio in Turin a papyrus fragment containing an excerpt from The Teaching of Khety, also known as The Satire of the Trades. ${ }^{1}$ Some years later (14 September 1983) he identified yet another fragment with a passage from Khety close to the one on the previously discovered fragment. As Roccati realised, it was an important find, for together the two fragments constituted the second half of Khety (chapters 21-30), thus providing a welcome additional source for this portion of the text, which was less frequently copied by the ancient Egyptian scribes than the more attractive first part that describes the various laborious professions. Moreover, the manuscript provided a good, although not faultless, version of the composition, which is infamous for its unintelligibility due to the many mistakes and variants occurring in the source material. Roccati made use of the papyrus for his translation of Khety that appeared in 1994 as part of an anthology of ancient Egyptian texts. ${ }^{2}$ This, however, remained largely unnoticed by the scientific community. Roccati again pointed out the existence of the papyrus in an article published in 2000 in which he also provided a transcription of four 


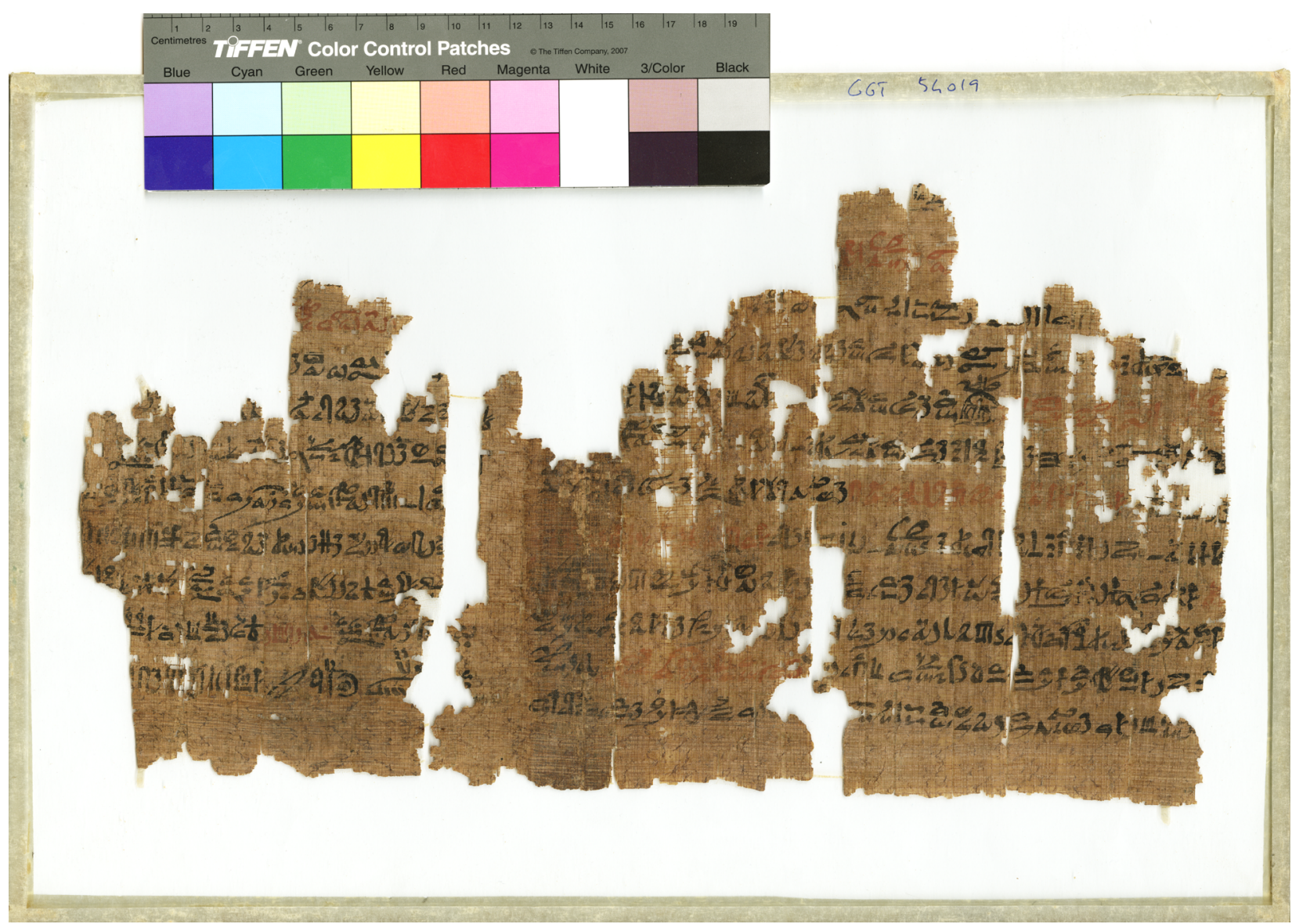

Fig. 1: CGT 54019, recto, mounted in frame 1 (columns 2 and 3). Scan by the Museo Egizio.

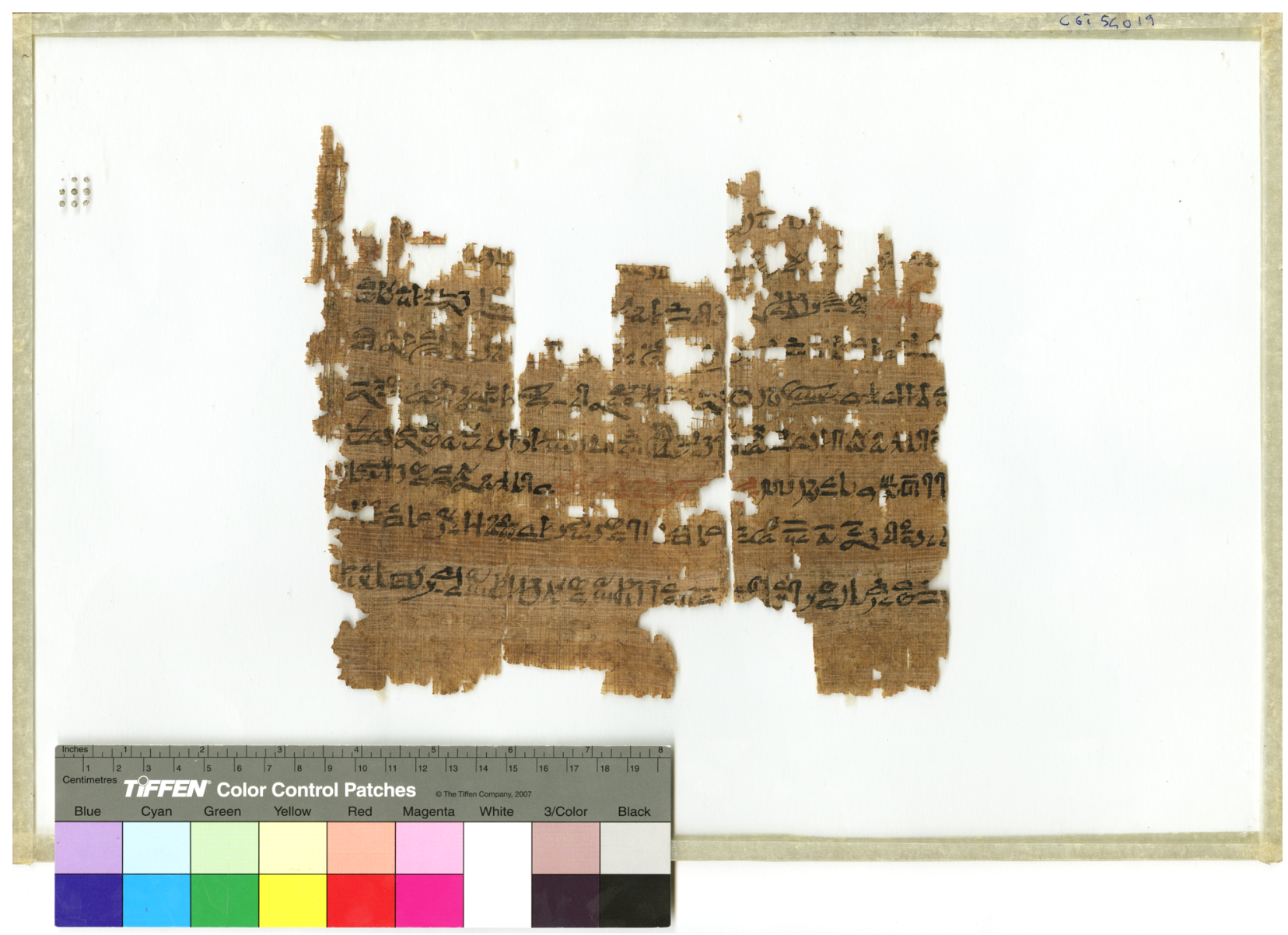

Fig. 2: CGT 54019, recto, mounted in frame 2 (column 1). Scan by the Museo Egizio. 
non-continuous lines. ${ }^{3}$ This was noted by Stephan Jäger, who published a new edition of Khety in 2004. He does mention the papyrus as one of the sources of Khety, but since he had no access to the manuscript, its text is not included in his edition. ${ }^{4}$

The numbers Roccati assigned to the papyrus have been the cause of some confusion. On several occasions, Roccati refers to the papyrus in its entirety (i.e. the two fragments together) as P. Turin CGT 54017, and hence so does Jäger, following Roccati. In one of his articles Roccati lists, among various (unpublished) papyri in the Turin museum, a "P. Turin CGT 54017: Satira dei Mestieri (=pSallier II 9,5-11,5). Identificato l'8.9.1978". Beneath this entry, however, he lists another papyrus "P. Turin CGT 54018: come il precedente. Identificato il 14.9.1983". The latter can only refer to one of the two fragments identified by him, since no other substantial manuscript containing Khety has so far been discovered amongst the papyri in Turin. ${ }^{6}$ However, Roccati's numbers are incorrect, for neither CGT 54017 nor CGT 54018 contain excerpts from Khety. ${ }^{7}$ P. Turin CGT 54019 (TPOP Doc ID 543), on the other hand, fits Roccati's description of the papyrus nicely, and the evidence suggest this must be the manuscript he discovered in the Turin collection. Part of the confusion seems to have arisen from the fact that the papyrus consists of two fragments mounted in two separate frames (Fig. 1 and Fig. 2), both of which were identified by Roccati some years apart. In this paper I will not only provide the first hieroglyphic transcription of CGT 54019 to appear in print, and discuss variants of the text, but also contextualise the papyrus based on its colophon.

\section{Description of the papyrus}

P. Turin CGT 54019 survives in two fragments that are mounted in two separate frames. The largest of the two fragments (Frame 1) measures $38 \times 20$ $\mathrm{cm}$ (Fig. 1). The smaller one (Frame 2) measures $21 \times 18.5 \mathrm{~cm}$ (Fig. 2). The numbering of the frames is misleading, for the fragment in frame 2 actually precedes the fragment in frame 1. Hardly anything is missing between the two pieces, so that they can almost be joined directly, having become separated only by a vertical crack (for a virtual reconstruction, see Fig. 3). Similar cracks appear throughout the manuscript at regular intervals (approximately $7 \mathrm{~cm}$ apart), suggesting that the papyrus was rolled-up and subsequently pressed down. The papyrus has suffered further damage, resulting in a number of lacunae. The verso is blank, apart from some traces of red ink, which may be pen trials or the remnants of a doodle (Fig. 4). The recto contains three columns of hieratic text written in horizontal lines. The first column is missing approximately $2.5 \mathrm{~cm}$ at the beginning; the second column is preserved to its full width $(23 \mathrm{~cm})$; the third column has lost about $10 \mathrm{~cm}$ at the end, assuming it had the same width as the other two. It seems likely that the manuscript once contained the entire composition, and thus that several sheets preceded the column now numbered 1 . The third column contains the end of Khety followed by a colophon. It is likely that this also constituted the end of the papyrus, as the handwriting in the third column appears denser, as if the scribe was doing his best to finish the text within the available space. While the length of the papyrus

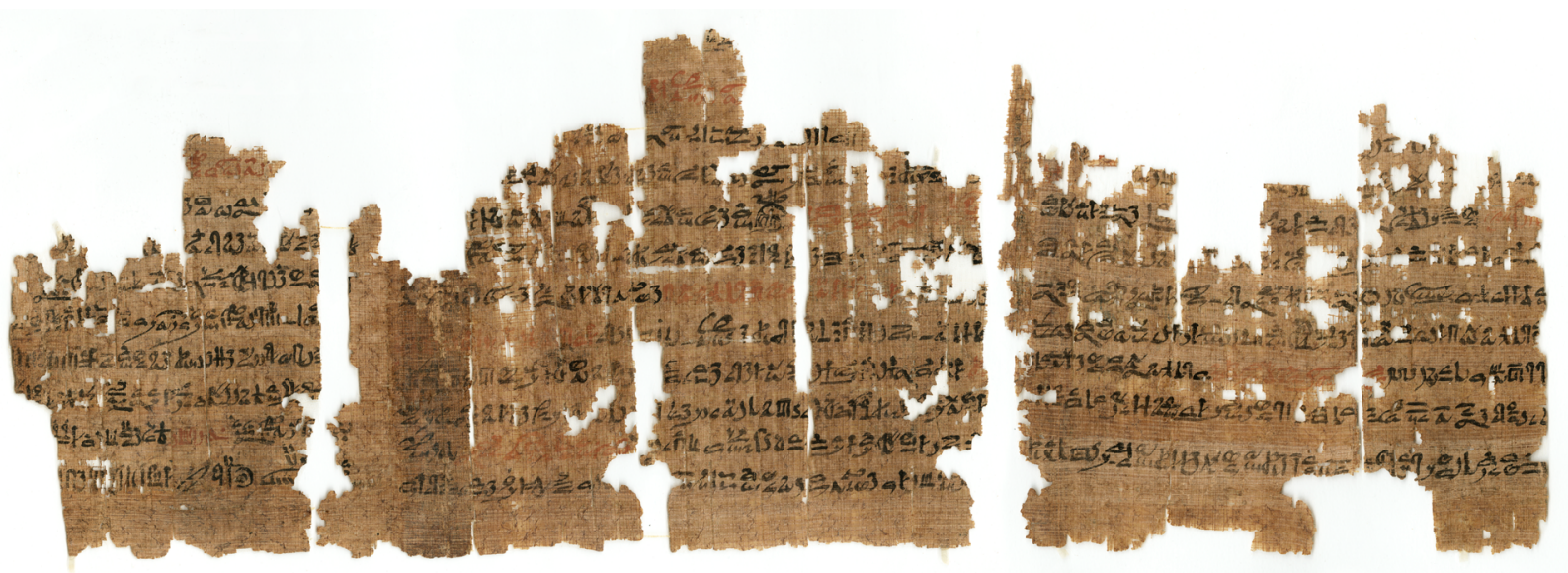

Fig. 3: Virtual reconstruction of CGT 54019 by the author, based on scans by Museo Egizio. 

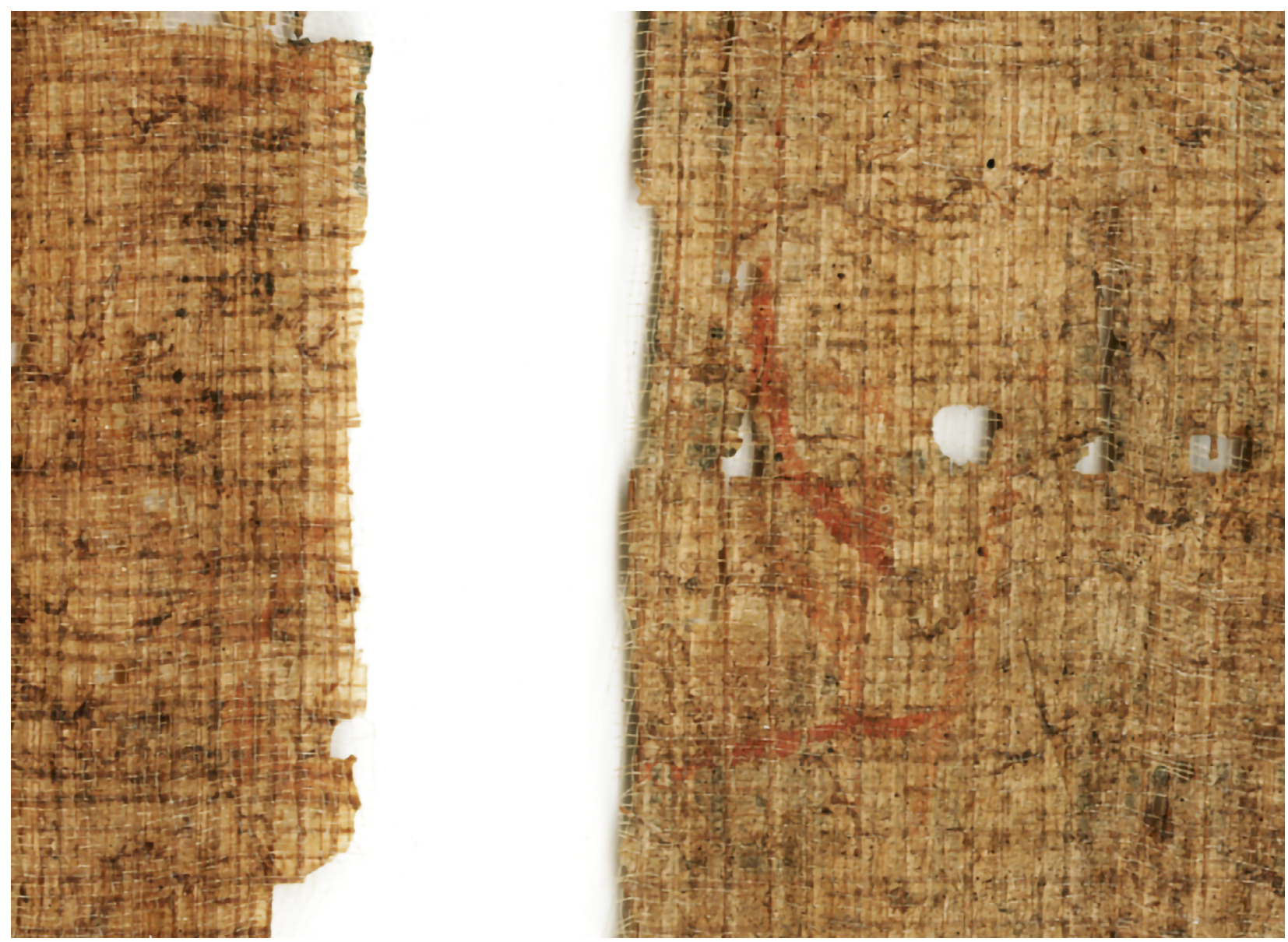

Fig. 4: CGT 54019, detail of the verso. Scan by the Museo Egizio (with colour enhancement by the author).

is thus incompletely preserved, its height seems to have survived more or less intact. The lower margin is preserved in its entirety. Assuming the top margin measured the same as the lower one $(2 \mathrm{~cm})$, the total height of the papyrus would have been slightly over $20 \mathrm{~cm}$, which corresponds to a half-roll, a full papyrus roll mostly measuring between 41 and 43 $\mathrm{cm}$ in height in the Ramesside Period. ${ }^{8}$ In the top margin above the second column some traces of writing are visible that are not part of the main body of text. They might belong to a writing exercise, or perhaps to a date; such features also appear in the margins of other papyri. ${ }^{9}$

\section{Provenance and date}

Nothing is known about the origin of the manuscript. There is no information about the papyrus provided in the museum records other than its current number. Most of the Ramesside papyri in the Museo Egizio stem from western Thebes and came into the possession of the museum when Bernardino Drovetti (1776-1852) sold his first collection to the king of Sardinia in 1824. Drovetti was not only the French consul in Egypt at the time, but also a collector of Egyptian antiquities, whose agents were particularly active on the Theban west bank, most likely including the workmen's village of Deir el-Medina. ${ }^{10}$ Other papyri now housed in Turin were excavated by Ernesto Schiaparelli (1856-1928) in Deir el-Medina. It is not known whether CGT 54019 originates from Drovetti's collection or from Schiaparelli's finds. However, since most of the papyri in the Turin collection seem to originate from the village of Deir el-Medina, western Thebes as a provenance is highly likely, also considering the colophon that refers to the mortuary temple of Ramesses III at Medinet Habu (see below). It is interesting the papyrus stems from this area, since both P. Sallier II and P. Anastasi VII (the only manuscripts containing more chapters of Khety than CGT 54019) are likely to have a Memphite origin. ${ }^{11}$ The manuscript dates from the Ramesside Period, more precisely the Twentieth Dynasty. The fact that Ramesses III is mentioned provides us with a terminus post quem. 


\begin{tabular}{|c|c|c|}
\hline Sign & $\begin{array}{l}\text { Reference } \\
\text { Möller }\end{array}$ & CGT 54019 \\
\hline 氞 & No. 39 & 2,10 \\
\hline 攻 & No. 47 & 9 \\
\hline 나 & No. 105 & 2,6 \\
\hline Sid & No. 191 & $\infty_{1}$ \\
\hline$\frac{\pi}{2}$ & No. 204 & \\
\hline $\cos$ & No. 229 & \\
\hline ใ & No. 237 & \\
\hline$\sqrt{p}$ & No. 279 & \\
\hline$\odot$ & No. 303 & $e_{2,6}$ c \\
\hline 8 & No. 398 & - 2,9 \\
\hline$\eta$ & No. 478 & 3,6 \\
\hline$\rightarrow$ & No. 519 & 3,4 \\
\hline
\end{tabular}

Table 1: Overview of the signs showing features common in the Ramesside period.

\section{Palaeography}

The palaeography of the manuscript confirms its dating to the Ramesside Period (see Table 1). The scribe's handwriting is neat, free of ligatures, round, and of average size. He had a tendency to add dots to certain signs, e.g. $3 h(1,5), k 3(3,9), n d m(3,5)$, tyw $(1,4)$. Several signs are quite distinctive for this scribe and may help to identify other manuscripts written by the same person in the future. They are listed in Table 2. This table also includes the scribe's way of writing the pronoun $s t .^{12}$ To this may be added the scribe's peculiar spelling of the word $h_{3} b(2,7$; $2,9 ; 3,2)$ and his consistent writing of $(w n)$ as (1,2; 2,10; 3,7; see also below), an example of Late Egyptian orthography. The manuscript lacks

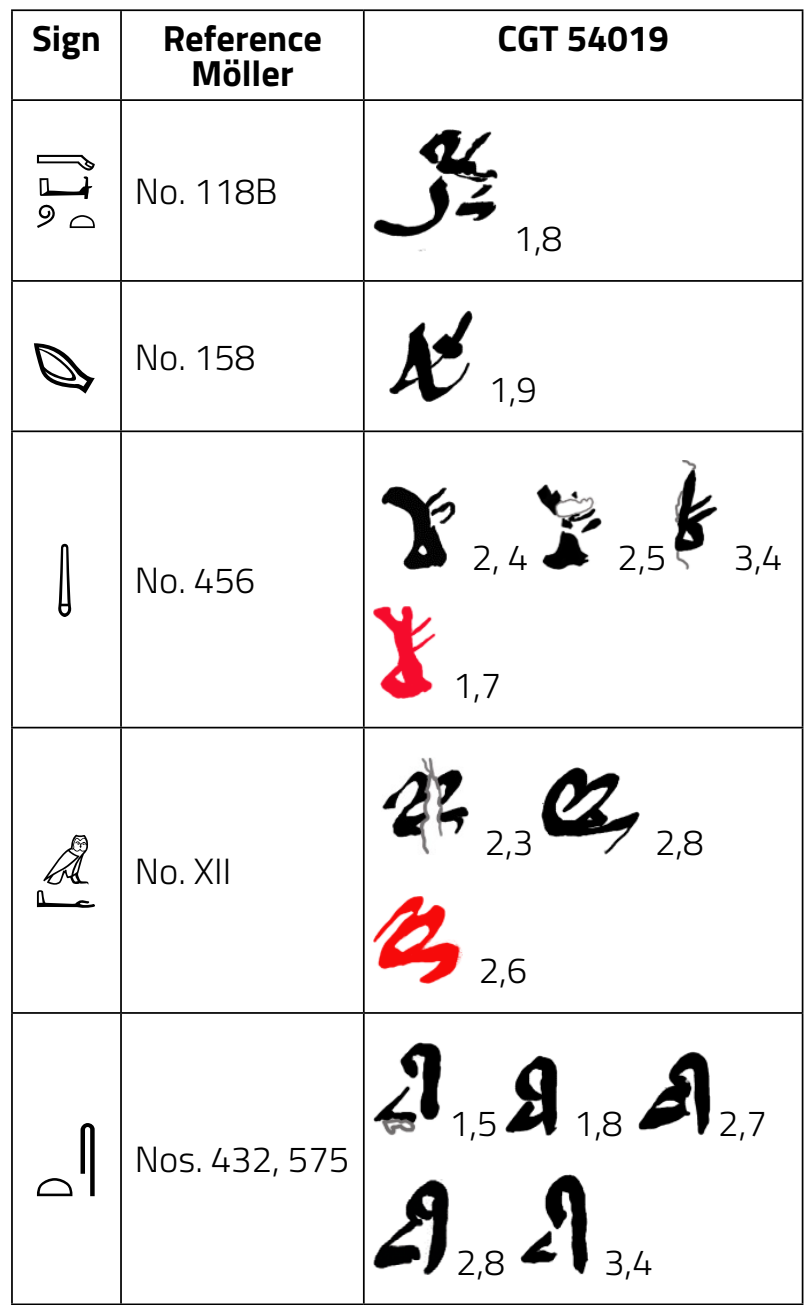

Table 2: Idiosyncratic signs of the scribe of CGT 54019, including his distinctive writing of the pronoun st.

verse points. ${ }^{13}$ This is a noteworthy feature, since the use of these "verse points" was widespread in the New Kingdom, especially in literary texts. ${ }^{14}$

\section{Hieroglyphic transcription and commentary}

The Teaching of Khety is known for its many mistakes and variants, making it a notoriously difficult text, to such a degree that John Foster remarked: "The so-called Satire on the Trades, containing Khety's instruction to his son Pepi, is one of the most confusing, garbled, and unintelligible literary texts to survive from ancient Egypt." ${ }^{15}$ CGT 54019 contains some variants that are unparalleled in the other source material of Khety. ${ }^{16}$ Many of these help to 
shed light on obscure passages of the composition. The papyrus can therefore be said to provide a more legible version of the text than many other sources, although it is certainly far from faultless.

In the past, variants that occurred in manuscripts were often seen as mistakes, a corruption of the perfect text originally composed by the author. Philologists tried to identify these "errors" in order to reconstruct a hypothetical Urtext. The most recent edition of Khety by Stephan Jäger is a good example of this traditional approach. Jäger makes use of stemmata to establish a hierarchy of manuscripts and uses the results to reconstruct an Urtext. ${ }^{17} \mathrm{Cer}-$ quiglini, however, has convincingly argued that it is impossible and indeed irrelevant to retrieve an original text from supposedly faulty copies, for "medieval writing does not produce variants; it is variance," and "every copy is alteration", meaning that variants and mistakes are an inherent feature of textual transmission. ${ }^{18}$ Recently this approach, known as "New Philology" or "Material Philology", has also found footing within Egyptology. ${ }^{19}$

Variants thus have a value of their own; they may offer insights into the social conditions of textual production. As early as the 1970s, Burkard analysed mistakes and variants in ancient Egyptian wisdom texts, including The Teaching of Khety. Regarding the latter, he concluded that the sources contained many reading errors ("Lesefehler"), a few memory mistakes ("Gedächtnisfehler") and no hearing errors ("Hörfehler"). Thus, according to his analy- sis, the preferred method of textual transmission was copying the text from another manuscript as opposed to writing from memory (which did occasionally occur) and copying from dictation. ${ }^{20}$

True to the old philological tradition, Burkard saw many variants as mistakes, but in reality it is often difficult to identify the purpose behind a particular variant: whether it is a real error, made unconsciously by the scribe, resulting in a faulty (sometimes incomprehensible) version of the text; a "conscious" modification, for example when a scribe did not remember a particular detail and replaced it with something else; ${ }^{21}$ or a redactional variant, the scribe knowingly adapting the text, for example to facilitate the understanding of a sentence or to update the text, for instance by using Late Ramesside orthography. A further difficulty lies in discerning if the mistake or variant was made by the copyist himself or if it was already part of a corrupt textual tradition, the scribe faithfully copying the text as he knew it. ${ }^{22}$ Either way, the study of variants can reveal much about the engagement (or non-engagement) of the scribe with the text he copied.

In the following section I will comment on the variants of CGT 54019 that are unparalleled in other sources. It falls outside the scope of this paper to give a detailed analysis of every variant of the manuscript (a full new edition of The Teaching of Khety is in preparation by the present author), but the discussion below will touch upon the matters discussed above.

\subsection{Column 1: chapters $21,4-23,4$}

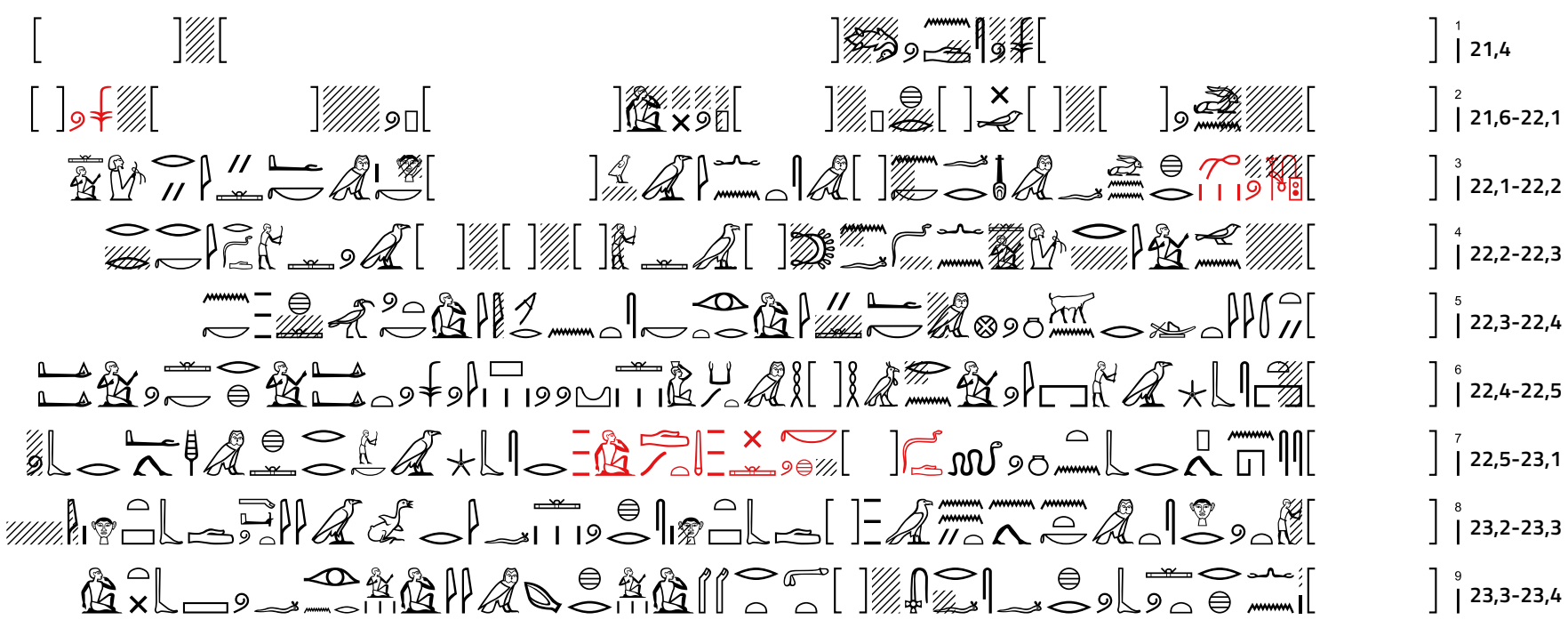




\section{Chapter 21}

\begin{tabular}{|l|l|l|}
\hline & {$[\ldots]$} & {$[\ldots]$} \\
\hline 21,4 & {$[\check{s} p . n] s w$ snd } & Fear [has blinded] him. \\
\hline 21,5 & {$[\ldots]$} & {$[\ldots]$} \\
\hline & {$[\ldots]$} & {$[\ldots]$} \\
\hline 21,6 & {$[m=k n n] w n[\grave{l} s w . t \check{s} w . t]$ hrp $[. w]$} & {$[$ Look, there is [no profession free of] supervisors, } \\
\hline & {$[w] p w[s \check{s} n t f h r] p$} & except for [that of scribe: he is the] supervisor. \\
\hline
\end{tabular}

\section{Chapter 22}

\begin{tabular}{|c|c|c|}
\hline \multirow[t]{3}{*}{22,1} & {$[i r] s w[t r h=k] s \check{s} . w$} & But [if you know] writing, \\
\hline & $h r$ wnn=f $m n f r \quad n=k[i] m=s t$ & then it will go well with you because of it. \\
\hline & $n n i 3 w[. t][\ldots] h r=k$ & There are no professions [...] your face. \\
\hline \multirow[t]{3}{*}{22,2} & $m=k i r j[h w r] n=i ̉ i r j$ & Look, the subordinate! [Miserable is] the subordinate to me. \\
\hline & $n n \underline{d}[d] n=f c h w . t j[\ldots]$ & A field worker will not say to him [...] (?) \\
\hline & {$[m s] 3 w r \underline{d} d i r r=k$} & [Beware] of speech about you. \\
\hline \multirow[t]{2}{*}{22,3} & $\{r\}<i>r[\ldots][\underline{h} n] t y t r \underline{h} n w$ & [...] travelling southwards to the Residence, \\
\hline & $m=k$ i. ir $r=k$ st $n$ mrw.t=k & look, you have done it for love of yourself. \\
\hline \multirow[t]{2}{*}{22,4} & $3 h n=k[h r w m][] . t-s b_{3}$ & [A day in school] is beneficial for you, \\
\hline & $\grave{\imath} w=\hat{\imath} r n h \underline{h} \mathrm{~m} k 3 . t \underline{d} w . w$ & while I will be forever in mountain labour. \\
\hline \multirow[t]{2}{*}{22,5} & $\grave{l} w$ swt $d d=\hat{l} r h=k$ & But while I will make you knowledgeable, \\
\hline & $d d[\ldots]$ ssnhp r bth.w & [...] will cause ...? ... against ...? ... \\
\hline
\end{tabular}

\section{Chapter 23}

\begin{tabular}{|c|c|c|}
\hline \multirow[t]{2}{*}{23,1} & $\underline{d} d[=i n=k] k[t] h . w m d . w t$ & [I] I will say other words [to you], \\
\hline & $r s b_{3}=k r r h$ & to teach you knowledge. \\
\hline \multirow[t]{2}{*}{23,2} & 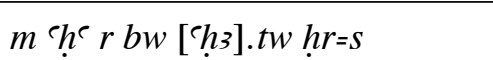 & Do not stand at a place where there is [fighting]. \\
\hline & $m\{n\} t k n n$ ntyw $\underline{d b} . t$ h $r$ shr.w. $f$ & $<$ Do $>$ not $<$ be close $>$ to those on whose plans is a brick. \\
\hline \multirow[t]{2}{*}{23,3} & $i r \underline{t} 3 j . t w d \underline{d b t} h r \quad i[n \quad 3 s-i b]$ & If a brick is taken [by a hasty-hearted person], \\
\hline & $n n$ rh.tw bw hr=f srf[...] & one will not know the place where he is, being hot [...] (?) \\
\hline \multirow[t]{2}{*}{23,4} & $m t r h r s \underline{d} m j . w$ & Testify before the judges, \\
\hline & $\operatorname{ir} n=f w s ̌ b[\ldots]$ & answer him $[\ldots]$ \\
\hline
\end{tabular}

21,6 (column 1, line 2): [m=knn] wn [izw.t šw.t] hrrp[.w] The variant $n n w n$ instead of $n n$ also occurs on $\mathrm{O}$. DeM 1562 and on an unpublished ostracon (O. Ashmolean HO 576). There is no apparent difference in meaning between the two constructions. ${ }^{23}$

\section{2,1 (column 1, line 3): $h r w n n=f m n f r n=k[i] m=s t$}

The papyrus shares the phrase $h r w n n=f(m)$ with all the other sources, with the exception of writing tablet Louvre 693, which reads $w n n f r n=k$ st. The latter is considered the grammatically better variant, while $h r w n n=f$ has been written under the influence of Late Egyptian. ${ }^{24}$ The variant $i m=s t$ instead of $s t$ occurs nowhere else. Instead of the adjectival sentence $n f r n=k s t$, "it is good for you", the scribe may have had in mind the expression $n f r n=k$, "it is good for you", "you are well", in which the subject ("it") is unexpressed. ${ }^{25}$ Because $s t$ had become superfluous, ${ }^{26}$ the scribe may have written $i m=s t$ to overcome this problem. Alternatively, the scribe may have inserted im before $s t$ unthinkingly, the combination im=st being very common. Compare chapter 26,2 where the scribe has also written im=st instead of $s t$ (see below). 
22,2 (column 1, line 4): [m s]3w r d $d \dot{i r}=k$

The papyrus uses the preposition $r$ after $s 3 w$, which is not present in the other witnesses. There are various possible explanations for its occurrence here. First of all, the scribe may have added the $r$ mechanically, having the common expression $r$ - $d d$ in mind. Secondly, s3w can be constructed with the preposition $r$. Lastly, $r . d d$ may stand for $i . d d$, "that which is said". ${ }^{27}$ Whether the translation suggested above is correct depends on the meaning of the previous sentence, which is unfortunately obscure. Most translators render it along the lines of "a farmer is not called a man,, ${ }^{28}$ in which case the suggested translation would fit. ${ }^{29}$ I follow most translators in emending $m s 3 w$ or $s 3 w$, assuming that the lacuna of our papyrus also contained a negative imperative like the other sources. There seems to have been confusion between $m s 3 w$ and $s 3 w$, as it is used interchangeably between sources, for example in chapter 24,4 and chapter 28,5 , both obscure passages.

22,3 (column 1, lines 4-5): $\{r\}\langle i>r[\ldots][\underline{h} n]$ tyt $r \underline{h} n w$ The scribe seemingly starts this verse with 0 . Because of the lacuna that follows, it is difficult to say whether this really constitutes a new variant or is simply a miswriting for $\infty$ as written in the other sources, although in the latter cases it is mostly preceded by $m=k$.

\section{2,3 (column 1, line 5): $m=k$ i. ir $=k$ st $n$ mrw. $t=k$}

The use of the emphatic form $i . i r=k$, placing special emphasis on $n m r w . t=k$, is unparalleled in the other sources. The prothetic yod used in the emphatic form is a Late Egyptian feature. ${ }^{30}$ Instead of $=k$, the verb is followed by the suffix $=i$ in all the other sources (although omitted): "Look, I have done it for love of you". This makes more sense, as it is the father who takes his son to school in the Residence. Whether the $=k$ should be considered a mistake or a deliberate variant can no longer be established as it depends on what was originally written in the lacuna in the previous verse.

\section{2,4 (column 1, line 6): ỉw=i $r$ nhh $m k 3 . t \underline{d} w . w$} CGT 54019 differs from all the other sources in employing $i w=i$ instead of $i w$, which leads to the question whether $i w$ in the other manuscripts should be considered as $i w=i$ with the suffix pronoun $=\dot{i}$ left out, rather than a Late Egyptian writing for $r$, as suggested by Jäger. ${ }^{31}$ The construction $i w=\hat{\imath} r n h h$ occurs more often, ${ }^{32}$ cf. also $m$ k3.t $n h h$, "in ewig dauernder Arbeit". ${ }^{33}$ The expression $k 3 . t \underline{d} w . w$ does not occur elsewhere, although it is similar to other combinations referring to manual labour, such as for example k3.t (n.t) sh.t, "the work of the field"; cf. $W b$ V.98.8-14. As the previous sentence reads "A day in school is beneficial for you", the condition of the son is contrasted with that of his father who may have been a commoner, as he is simply called a "man from Sile" in the introduction. ${ }^{34}$

\section{2,5 (column 1, line 6): iw swt $d d=i \quad r h=k$}

The papyrus employs the word swt, "but", which is unattested in the other known sources. Its addition may reflect an attempt by the scribe to emphasise the contrast with the preceding sentence discussed above. Despite the added word, the sentence is shorter than the corresponding verse in P. Sallier II. While the latter needs emendation to be understood, the meaning of our sentence is clear. Furthermore, this shorter variant seems to correspond with P. Anastasi VII's version of the text. This papyrus has a lacuna before $d i=i \quad r h=k$ that is clearly not long enough to contain P. Sallier II's version of the text, although Jäger's and Helck's transcriptions suggest otherwise. The length of the verse and the remaining words are in fact comparable to CGT $54019 .{ }^{35}$ The suffix $=k$ written as $=k w j$ is yet another example of the various Late Egyptian spellings found in this papyrus.

\section{2,5 (column 1, lines 6-7): $d d[$ [...] ssnhp $r$ bthn.w}

The verse uses the word ssnhp, whereas it is spelled sshp, ssh $3 p$ or snhp in the other sources. Its meaning is obscure (cf. Wb IV.278.10; Wb IV.168.1-4). The use of the preposition $r$, which is unparalleled in the other sources, makes it impossible to consider $b \underline{t} n . w$ an object to the verb ssnhp, as most translators do.

\section{3,1 (column 1, line 7): $r s b 3=k r r h$}

This otherwise unattested variant offers an easy comprehensible sentence, in contrast to the other sources. The verb $s b_{3}+$ object $+r$ means "jem. erziehen zu ..., "jem. in einer Tätigkeit unterweisen”, in this case knowledge ("im Wissen"). ${ }^{36}$ 


\section{3,2 (column 1, lines 7-8): $m$ r h $r$ bw ['h3].tw $h r=s$} The sentence differs widely from the corresponding ones in the other sources. It provides an easy translation, while the other variants are difficult to understand without emendation. The occurrence of $m$ before $h^{c}$ makes it clear that this should be considered a negative imperative, as jäger suggested. ${ }^{37}$ The phrase $h r=s$, used only here, is a good alternative to the more common im, as "h $h$ mit $h r$ " means "an einem Ort kämpfen”. ${ }^{38}$

23,2 (column 1, line 8): $m\{n\} t k n n n t y w \underline{d} b . t$ hr shr.w=f The sentence is close to the version in P. Sallier II, but is obscure as it stands and emendation is needed. The phrase ntk $n\left(\Omega_{1}\right)$ is a Late Egyptian expression (Wb II.195.5) and is here a corruption for $m t k n n$, "do not be close to",39 as written in P. Anastasi VII. ${ }^{40}$ The scribe of P. Sallier II repeats the same mistake later on, writing $n t k n$ where $t k n$ should be read. ${ }^{41}$ The second part of the sentence may be an ancient Egyptian expression unknown to us, perhaps referring to people with a violent nature.
23,3 (column 1, lines 8-9): ir tisj.tw db.t i [n $3 s-i b]$ If the brick mentioned in this sentence relates to the one in the previous verse, it may be that $t 3 j$ is not used here in the sense of "stealing", as most translators understand it, but of "taking up". The hasty-hearted person has grabbed one without thinking, seemingly with the intention of throwing it in a fight. The throwing of bricks ( $\left.h_{3}{ }^{c} \underline{d} b . t\right)$ also features in P. Chassinat $\mathrm{I}, \mathrm{x}+7$. In this story King Neferkare, standing outside Sasenet's house, throws a brick and stamps his foot to get the attention of his general. ${ }^{42}$

\section{3,3 (column 1, line 9): $n n$ rh.tw $b w$ hr $r=f s r f[\ldots]$}

This verse differs from the corresponding one in the other known manuscripts. All the elements of the sentence occur elsewhere, but not in this order. The sentence begins, as in all the other sources, with $n n$ $r h . t w$. Jäger's emendation to $n$ rh.n.tw seems to me to be unnecessary, as the phrase can be interpreted as a negation of the subjunctive with future meaning. ${ }^{43}$ The verse is corrupt. The expression $b w h r N$, "da wo $\mathrm{N}$. ist", which is seemingly written here, is uncommon and only occurs in Late Egyptian. ${ }^{44}$ As a consequence, the meaning of the sentence is obscure. ${ }^{45}$

\subsection{Column 2: chapters $24,1-28,3$}

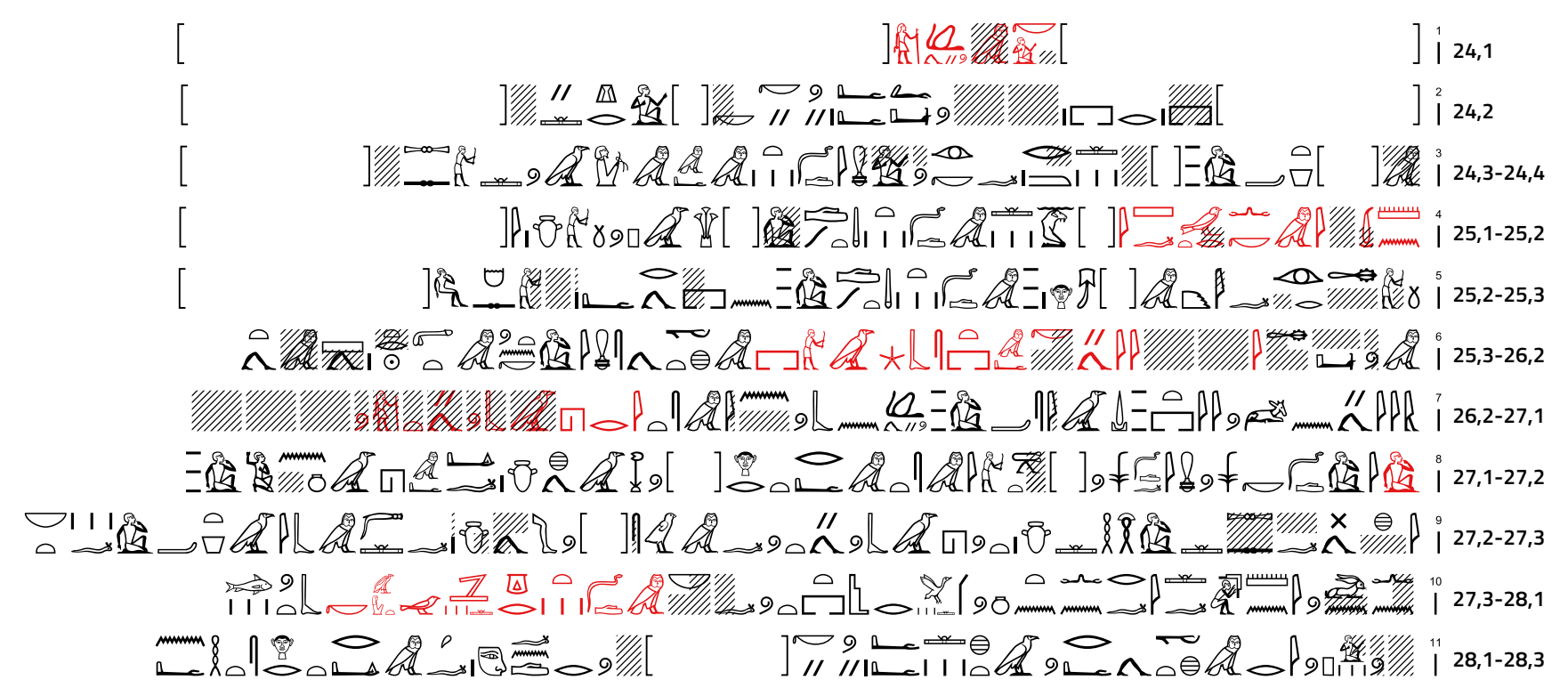




\section{Chapter 24}

\begin{tabular}{|c|c|c|}
\hline \multirow[t]{2}{*}{24,1} & {$[i ̉ r \check{s} m]=k m p h . w j s r[. w]$} & [If] you [walk] behind noblemen, \\
\hline & {$[\ldots]$} & {$[\ldots]$} \\
\hline \multirow[t]{2}{*}{24,2} & {$\left[i r c_{k}=k i w n b\right] p r r p r$} & [If you arrive while the master of] the house is in the house, \\
\hline & $[\ldots]$ C.wj $=k j k[y] \underline{h r} r \ldots]$ & {$[\ldots]$ your arms, while someone else is under $[. .]$.} \\
\hline \multirow[t]{2}{*}{24,3} & {$[\ldots]$} & {$[\ldots]$} \\
\hline & $m[d b h$ h.t $t] r-g s=f$ & [Do] not [ask for the things] at his side. \\
\hline \multirow[t]{2}{*}{24,4} & $i r=k m i \grave{d} d . t m-m$ & May you do according to what was said among them. \\
\hline & $\{m\} s 3 w \underline{t}[s[\ldots]$ & Beware of $[\ldots]$ \\
\hline
\end{tabular}

\section{Chapter 25}

\begin{tabular}{|c|c|c|}
\hline 251 & 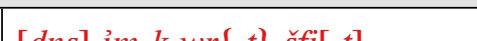 & [Re weighty] in vourself great of resnect \\
\hline \multirow[t]{2}{*}{25,2} & $m d d m d[. w t \quad n . t] h_{3} p i b$ & Do not tell secrets [of] the heart. \\
\hline & $i\left[w h h_{3} p\right] \underline{h}[. t] \operatorname{ir}[. n]=f i k m h \underline{h r=w}$ & $\begin{array}{l}\text { [One who hides] his inner thoughts [has] made a shield } \\
\text { concerning them. }\end{array}$ \\
\hline \multirow[t]{2}{*}{25,3} & $m \underline{d} d \mathrm{md} . w t n$ prj-؟[-ib] & Do not speak reckless words, \\
\hline & $h m s i[\ldots][k s] m \underline{h}[. t]$ & sitting [...] someone who is defiant. \\
\hline
\end{tabular}

\section{Chapter 26}

\begin{tabular}{|c|c|c|}
\hline \multirow[t]{2}{*}{26,1} & $i[r p r] j=k m c^{c} t-s b_{3}$ & If you leave the school, \\
\hline & $m$-ht smj.tw $n=k$ mtr.t & after midday is announced to you, \\
\hline \multirow[t]{2}{*}{26,2} & šm.t ỉj $n \grave{l w y . w t}$ & (after) coming and going in the streets, \\
\hline & dusis ph.wj $n$ bw $n[t k]$ im $=s t$ & advise the end of the place where [you] are. (?) \\
\hline
\end{tabular}

\section{Chapter 27}

\begin{tabular}{|c|c|c|}
\hline \multirow[t]{3}{*}{27,1} & $i r h_{3} b \underline{t w} \operatorname{srj}[m w p . t]$ & When a magistrate sends you [with a message], \\
\hline & $i . d d=k s w m j \underline{d} d=f s w$ & you shall say it as he said it. \\
\hline & 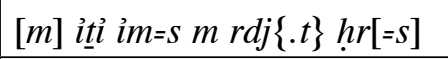 & Do [not] take away from it; do not add to [it]. \\
\hline \multirow[t]{3}{*}{27,2} & {$[\hat{\imath}] w h 3 h-i b d \dot{l}=f\{m\} h n w$} & A quick-thinking-one causes jubilation. \\
\hline & $i h[\ldots][d i]=f \underline{t z} w 3 h-i b$ & [...] [causes] kind speech \\
\hline & $\{t\}<i>w h 3 b . t w=f m w s[\underline{t} n]$ & He is sent unhindered. \\
\hline \multirow[t]{3}{*}{27,3} & $i b=f m h m b i ̉ . t=f n b . t$ & He trusts in all his good character traits. \\
\hline & $n n$ wn $i m n\{=f\} \grave{i r}=f$ & There are no secrets for him. \\
\hline & $n n \underline{\underline{t} n . w}$ r s.t $=f n b[. t]$ & There is no one promoted in any position that is his. \\
\hline
\end{tabular}

\section{Chapter 28}

\begin{tabular}{|l|l|l|}
\hline 28,1 & $m \underline{d} d d g r g . w<r>m w . t=k$ & Do not tell lies against your mother: \\
\hline & $b w . t[s r . w] p w$ & it is the horror [of noblemen]. \\
\hline 28,2 & $i r m-h t r d j . w h . w t$ & After things have been given, \\
\hline & $\ulcorner. w j=k j[\ldots] r$ fnd $=f$ & your arms [...] his nose. \\
\hline 28,3 & $m r d j h r=s t h n^{c}[\ldots]$ & Do not add to it with [...] \\
\hline & {$[\ldots]$} & {$[\ldots]$} \\
\hline
\end{tabular}


24,2 (column 2, line 2): [ir $\left.\Upsilon^{k}=k i w n b\right] p r r p r$

CGT 54019 has $r p r$, whereas all the other known sources have $m p r=f$, with similar meaning. ${ }^{46}$

\section{4,2 (column 2, line 2): [...] ৎ.wj=kj $k[y] \underline{h r} r[\ldots]$}

The lacuna preceding $\varsigma . w j=k j$ may once have contained $h_{3} m$ or $h_{3} b$, "bend (the arms)", as Jäger suggested ${ }^{47}$ although the traces of ink are inconclusive. Before an $m$ seems to have been written, but the supposed signs for 3 and $h_{3}$ are a little different in shape than their counterparts in this papyrus. ${ }^{48}$ The variant $\varsigma . w j=k j$ is unparalleled in the other sources, which all have ${ }^{e} \cdot w j=f j$. On the one hand it confirms Jäger's emendation that $` \cdot w j=k j$ should be read and not $`$. $w j=f j$. On the other hand Jäger assumes that, after $\ulcorner. w j=k j$ had become $\ulcorner\cdot w j=f j$, the scribes added $k y$ to account for the otherwise functionless $=k j$. Our papyrus, writing both $=k j$ and $k y$, makes this suggestion less likely. ${ }^{49}$ While all other manuscripts have $r$ - $h 3 . t$ $=k$, the papyrus under discussion uses $\underline{h} r[\ldots]$, which has quite the opposite meaning. Unfortunately, what follows is unclear due to the fragmentary state of the papyrus.

\section{4,4 (column 2, line 3): ir=k mỉ d dd.t m-m}

The sentence can be read without emendation. The variant $i r=k$ is unparalleled. It confirms Jäger's suggestion that an imperative or an optative should be read here. ${ }^{50}$ Furthermore, the spelling of the adverb $m-m$ is more correct than its counterpart in P. Sallier II and P. Anastasi VII ()

\section{5,2 (column 2, line 4): $m \underline{d} d d m d[. w t ~ n . t]$ h.3p ib}

This is the only manuscript adding $i b$ after $h 3 p$. It may be a deliberate variant by the scribe to facilitate understanding.

25,2 (column 2, lines 4-5): $i[w \quad h 3 p] \underline{h}[. t] \operatorname{ir}[. n]=f$ ikm $h r=w$

The words $h r=w$ after $i k m$ are clearly an addition by the Ramesside scribe, making use of the Late Egyptian suffix pronoun $=w$. Again, it seems that his intention was to improve the understanding of the passage.

\section{5,3 (column 2, line 5-6): hmsi $[$...] [ks]m $\underline{h}[. t]$}

Nothing precedes $h m s i$, whereas in all the other sources this word is introduced by the particle $i w$ (and in one case $t w=k m$ ). This supports Jäger's suggestion to delete the $i w$ of the other sources. His reading of $h m s i$ as an imperative, ${ }^{51}$ however, cannot be confirmed due to the lacuna: it is uncertain whether or not $h m s i$ was followed by a suffix pronoun.

\section{6,2 (column 2, lines 6-7): šm.t ỉy $n$ ỉwy.wt}

The variant $n i w y . w t$ instead of $m i w y . w t$ is a Late Egyptian feature. $^{52}$

\section{6,2 (column 2, line 7): disis ph.wj $n$ bw $n[t k]$ im=st}

The variant $i m=s t$ instead of $s t$ is unparalleled in the other manuscripts, cf. chapter 22,1 (see above). This version of the text is reminiscent of the construction bw ntk im, "the place where you are", ${ }^{53}$ although due to a lacuna it is not clear whether $n t k$ was written here or $n=k$ as in the other sources. The meaning of the sentence is obscure.

\section{7,1 (column 2, line 8): $i . d \underline{d} d=k s w$ mj $\underline{d} d=f s w$}

Although the meaning of the sentence is clear, none of the sources provide a grammatically correct Middle Egyptian sentence. CGT 54019 adds yet another variant with clear Late Egyptian influence, although it is one of the more correct ones, coming closest to Brunner's emendation of the sentence ( $d d s w$ $m j \underline{d} d=f s w) .{ }^{54}$ The words $i . d d=k$ can grammatically be interpreted as an emphatic form. For its use in commands, see Erman, Neuaegyptische Grammatik, $1933^{2}, \S 308$. The prothetic yod is a Late Egyptian feature (see above). Another Late Egyptian influence relates to the dependent pronoun $s w$, which here refers back to a feminine word (wp.t in the preceding verse).$^{55}$ Assuming $d d=f$ to be a relative form, the second $s w$ is unnecessary. It is left out in the two variants that come closest to our version of the text: O. Turin 57082 (r. $\underline{d} d . t=k s w$ mj $\underline{d} d . t=f)$ and the unpublished ostracon Brussels E 6452 ( $i . d d=k s w ~ m j \underline{d} d=f)$.

27,1 (column 2, line 8): [m] ițỉ im=s $m$ rdì $\{. t\} \quad h r[=s]$ All other sources omit $i m=s$, except O. DeM 1529, where traces indicate that the word must have stood there originally, as now confirmed by CGT 54019.

27,2 (column 2, line 8): [i] w ḩ 3 -ib dil=f $\{m\} h n w$ The otherwise unattested word is not paralleled in the other sources, which have 
either $h n w$, “jubilation” (口 $i b$, "forgetfulness" ( O ). It seems the scribe of CGT 54019 had both variants in mind. He started writing $m h j-i b$, before deciding to write $h n w$ instead. Something similar may have happened on an unpublished ostracon from the mortuary temple of Merenptah, containing chapter 13,6 of Khety. Whereas the other sources have either the verb $m d \underline{d}$ or $w \underline{d}^{c}$, the scribe of this ostracon apparently began to write the former and midway changed his mind, continuing to write $w \underline{d}^{\mathrm{d}}$ instead. ${ }^{56}$ If so, it would indicate both scribes wrote from memory.

\section{7,2 (column 2, line 9): $i h[\ldots][d i]=f t z w 3 h-i b$}

The start of the verse differs from the other sources. It is likely the sentence parallels the preceding one. If so, the word $i h[\ldots]$ is to be interpreted as a noun, describing something positive.

27,2 (column 2, line 9): $\{t\}<i>w h 3 b . t w=f m w s[t h]$ CGT 54019 is the only manuscript which has the complete sentence. It is omitted by the other sources, except O. Turin 57082 and O. Brussels E 6452 (unpublished), where only the latter part of the verse has been preserved ( $m w \underline{w} \underline{t} n-i b$ and $[w s \underline{t} n]-i b$ respectively), and O. Louvre E 32896 (unpublished) and O. DeM 1576, which only preserve the beginning ( $h 3 b . t w$ and $i w h[3 b]$ respectively). The latter shows that $t w$ at the beginning of the verse should be emended to $i w$, in order to get a correct grammatical construction. Jäger suggested that the word wstn-ib on O. Turin 57082 was an "Individualfehler" ${ }^{57}$ However, CGT 54019 and the Brussels ostracon, both unknown to Jäger, clearly show this not to be the case. On the contrary, the five sources indicate that chapter 27,2 originally had a tripartite structure, like the preceding and following chapters $(27,1$ and 27,3$)$. The verse ends with wstn instead of wstn-ib. This appears to be a scribal error. Because the next verse starts with $i b$ (see below), the scribe omitted one of the two $i b$ 's (haplography). This kind of mistake is common in sources copied from another exemplar, but can also occur during copying from memory. ${ }^{58}$

27,3 (column 2, line 9): $i b=f m h m b i 3 . t=f n b . t$

The start of the verse $i b=f m h$ is unattested in the other sources, with two exceptions. O. DeM 1579 has $[\ldots]=f m h$ and it is now apparent that the word $i b$ should be read in the lacuna. O. Brussels E 6452 (unpublished) has [ ] most likely concerns the same variant, so that after $i b=f$ the word $m h$ would have followed.

\section{7,3 (column 2, line 10): $n n \underline{t}$ n.w r s.t=f $n b[. t]$}

CGT 54019 differs from the other manuscripts in employing $\underline{t} n . w$ instead of $\underline{t} n=f$. In contrast to the other sources no emendation is needed. The meaning of the sentence is similar to H.-W. Fischer-Elfert's interpretation: "nicht wird er suspendiert von welcher seiner Position auch immer" ( $n n$ tn $n . t w=f r$ s.t $f n b . t) .{ }^{59}$

\subsection{Column 3: chapters 29,1-colophon}

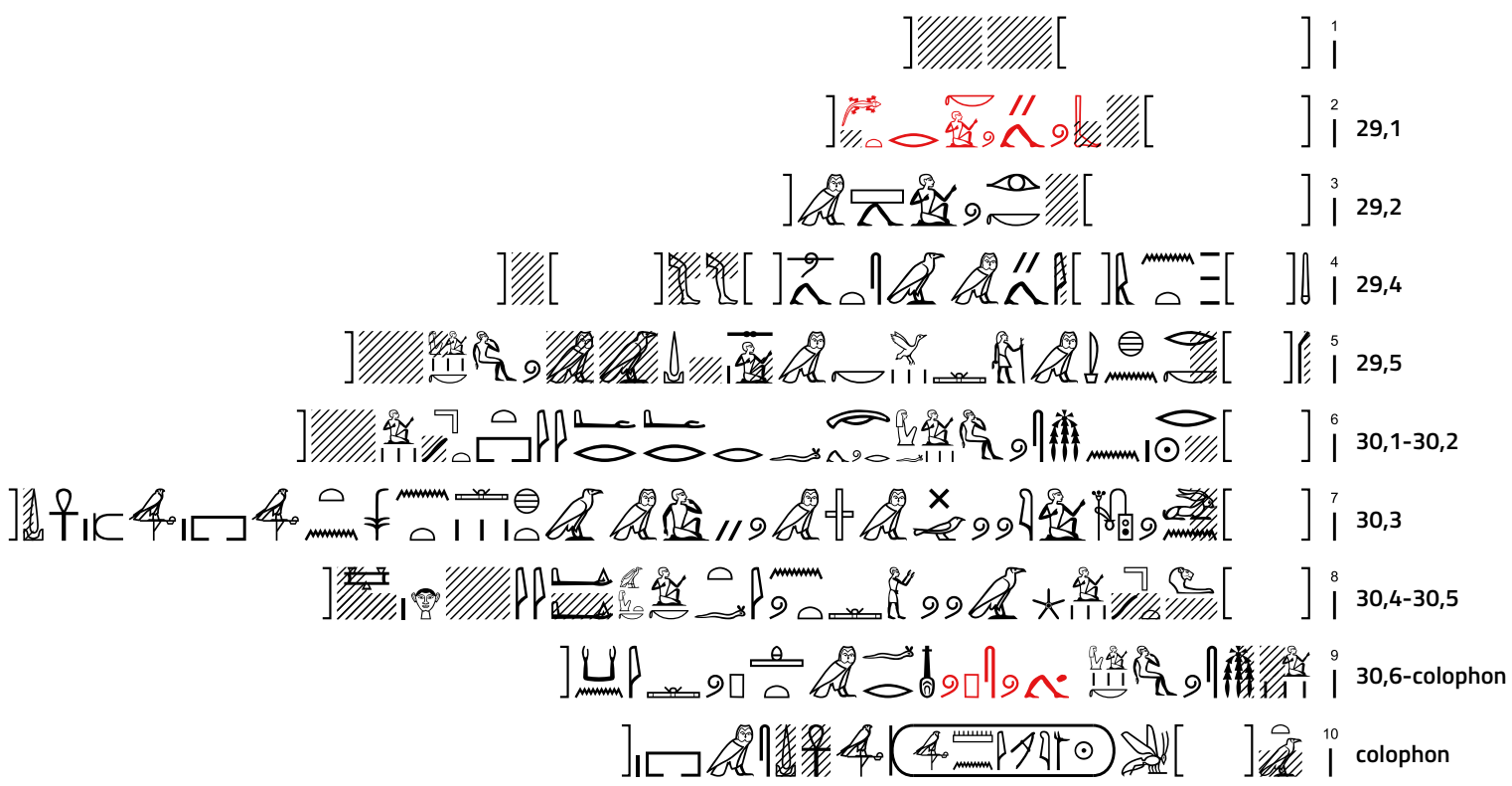




\section{Chapter 29}

\begin{tabular}{|c|c|c|}
\hline \multirow[t]{2}{*}{29,1} & {$\left[m=k n f r h_{3}\right] b=k r \check{C r}_{3}$} & [See, it is good that] you send (messages) often. \\
\hline & {$[\ldots]$} & {$[\ldots]$} \\
\hline \multirow[t]{2}{*}{29,2} & {$[\ldots]$} & {$[\ldots]$} \\
\hline & $i r=k \check{s} m[\ldots]$ & while you go [...] \\
\hline \multirow[t]{2}{*}{29,3} & {$[\ldots]$} & {$[\ldots]$} \\
\hline & {$[\ldots]$} & {$[\ldots]$} \\
\hline \multirow[t]{3}{*}{29,4} & {$[\ldots] m d . w t$ n.t $i j<. t j>$} & [...] words of welcome. \\
\hline & $m$ ss $[r d] . w j[=k j][\ldots]$ & Do not let [your] feet rush [...] \\
\hline & {$[\ldots]$} & {$[\ldots]$} \\
\hline \multirow[t]{2}{*}{29,5} & {$\left[s m_{3} m \underline{t} n . w\right] r=k$} & $\begin{array}{l}\text { [Associate with someone who is more distinguished] than } \\
\text { you. }\end{array}$ \\
\hline & $h n m s=k m s \underline{d} 3 m . w=k^{60}$ & May you befriend a man of your generation. \\
\hline
\end{tabular}

\section{Chapter 30}

\begin{tabular}{|c|c|c|}
\hline & {$[\ldots]$} & {$[\ldots]$} \\
\hline 30,1 & {$[h] r w n m s w<. t>=f$} & on the day of his birth. \\
\hline \multirow[t]{2}{*}{30,2} & $s p r=f r r^{e}{ }^{e} r y . t$ & He reaches the office, \\
\hline & $q n b . t[\ldots]$ & the council $[\ldots]$ \\
\hline \multirow[t]{2}{*}{30,3} & {$[m=k n n] w n s \check{s} \check{s} w . w m w n m$} & [Look,] there is [no] scribe devoid of eating \\
\hline & $m$ h.t n.t pr-nsw ${ }^{e}-w-[s]$ & from the food of the palace I.p.[h.] \\
\hline \multirow[t]{2}{*}{30,4} & {$[\ldots]$} & {$[\ldots]$} \\
\hline & {$[\ldots][\underline{h r}]-\underline{h} 3 . t$ qnb.t } & {$[\ldots]$ before the council. } \\
\hline \multirow[t]{2}{*}{30,5} & $\begin{array}{l}\{d w 3 . n . t w\}<d w 3-n \underline{t r} n>i t=k \\
m w . t=k\end{array}$ & $<$ Praise god for $>$ your father and your mother, \\
\hline & $d d y . w h r w z[. t][\ldots]$ & who are placed on the road [...] \\
\hline \multirow[t]{2}{*}{30,6} & {$[\ldots]$} & {$[\ldots]$} \\
\hline & {$[m s] . w m s . w=k$} & the children of your children. \\
\hline
\end{tabular}

29,1 (column 3, line 2): [m=k nfr $\left.h_{3}\right] b=k r \check{C}_{\mathfrak{S}_{3}}$

Whereas the other manuscripts employ $\check{S} \check{S} 3_{3}$, CGT 54019 has $r \check{S}_{\mathfrak{S}}$, which is an alternative way of writing the adverb. ${ }^{61}$ It makes clear $\check{\Upsilon} \breve{3} 3$ should be considered an adverb and not the object of $h_{3} b=k$, as some scholars assume. ${ }^{62}$

\section{9,4 (column 3, line 4): $m$ ss [rd].wj[=kj] [...]}

The papyrus has the negation $m$ before $3 s$, which is not present in the other sources. It confirms Jäger's suggestion that a negative imperative should be read here. ${ }^{63}$

29,5 (column 3, line 5): [sm $3 m$ tn.w] $r=k$

CGT 54019 has $r=k$, whereas the other sources have $r=s(t)$. It supports Helck's emendation of the text. ${ }^{64}$

30,2 (column 3, line 6): $s p r=f r$ erery.t

The spelling of the word erery.t is not otherwise attested. The other sources have ${ }^{c}$ cy.t / cy.t / rry.t / ry.t. $^{65}$

30,3 (column 3, line 7): $m$ h.t n.t pr-nsw c-w-[s]

The indirect genitive $n . t$ is spelled more correctly here than in the other sources (nty).

30,5 (column 3, line 8): $\{d w 3 . n . t w\}<d w 3-n \underline{t} r n \mid i t=k$ $m w . t=k$

As it stands, the verse starts with a $s \underline{d} m . n=f$ form. However, the use of the past tense does not suit the context here. Instead the signs $\mathrm{o}$ e are a mistake for 
the homophonous ntr that occurs in all other sources ( $d w z-n t r)$. The error indicates that the scribe copied the text from memory or while taking dictation. ${ }^{66}$

30,6 (column 3, line 9): [ms].w ms. $w=k$

The length of the lacuna makes it probable that a direct genitive was used instead of an indirect genitive as in the other sources.

\section{The colophon}

P. Turin CGT 54019 ends with a colophon, written after the closing words of Khety (column 3, lines 9-10):

$i w=s p w n f r m h t p i<n>k 3 n[\ldots]$

t3 [hw.t nsw] bity wsr-m3'ct-t-re mry-imn e-w-s $m$ pr [imn]

It is come, ${ }^{67}$ well and in peace. For the ka of [...] the [Temple of the King of Upper and] Lower Egypt, Usermaatra Meryamun, 1.p.h. in the domain of [Amun]

The phrasing of the colophon is typical for the New Kingdom. ${ }^{68}$ The expression $i w=s p w n f r m$ htp is followed by the standard dedicatory formula in $k 3 n$, although the scribe has curiously enough omitted the $n$ in the word $i n .{ }^{69}$ Unfortunately the name of the person to whom the text was dedicated is lost, as well as the name of the scribe himself, which usually followed, introduced by the words ir.n, "made by". The final line only preserves a reference to the mortuary temple of Ramesses III at Medinet Habu. ${ }^{70}$ The occurrence of a location (the temple of Medinet $\mathrm{Habu}$ ) in the colophon is noticeable, since this is very uncommon. In fact, locations are so rarely mentioned that this aspect of the colophon has not been discussed before in the Egyptological literature on colophons. In this section I will discuss the relevant examples in order to try to reconstruct the context in which the temple is mentioned in the colophon of CGT 54019.

Locations in colophons occur in three different types:

1. as the location where the king happened to be at the time of writing

2. as the location where the document was written

3. as part of the title of the scribe
Type 1 has only one example. The colophon in question concludes The Teaching of Khety on P. Anastasi VII. It reads as follows:

iw =s pw nfr $m$ ḥtp • in kз n š́ [pr-ḥd] $k_{3}\left[g_{3} b w\right] \cdot$

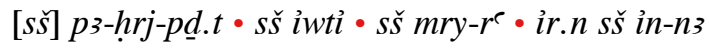
pз nb n tз sbзy.t • m rnp.t-zp 6 зbd 2 šmw sw 15 - iw $=t w$ m pr-re-msj-sw mry-imn-e-w-s-p3-k3-[e3]$n-p 3-r-h r w-3 h t j \cdot$

It is come, well and in peace. For the ka of the scribe [of the Treasury] Qa[gebu and the scribe] Paheripedjet and the scribe Iuti and the scribe Meryre. Made by the scribe Inena, the owner of the teaching, in year 6, second month of Summer, day 15, while One (i.e. the King) was in House-of-Ramesses-Beloved-of-Amun-l.p.h.,the[-Great]-Spirit-of-Pre-Harakhti. ${ }^{71}$

After the standard formulae of the colophon follows a date and the remark that the King was in Piramesse, the Ramesside capital in the Delta. Apparently, the scribe considered the event important enough to add to the colophon. It probably helped him remember the occasion when the papyrus was written. The phrase "while the King was in ( $i w=t w m)$ + location" is more often found outside the context of colophons, for example in the title of one of the Miscellanies, ${ }^{72}$ but mostly on administrative documents, from where it probably originates. ${ }^{73}$ This shows that scribes applied certain practices they used in administration also to their literary activities when deemed important.

Type 2 is also represented by a single example, namely the colophon at the end of the The Contendings of Horus and Seth. It reads: i $i w=s$ pw $n f r \quad m-\underline{h n} w$ wss.t $t 3$ s.t $t b$, "It is come, well in Thebes, the place of $t b "{ }^{74}$ Thus the colophon explicitly states that the papyrus was written in Thebes.

Type 3 occurs much more frequently. The relevant examples mostly name scribes $(s \breve{s})$ or draughtsmen $(s \check{s}-k d)$ in the "the place of Truth" $\left(s . t-m 3^{\bullet} . t\right)$, which refers to the Theban royal necropolis. ${ }^{75}$ The location does not indicate the place of production, but is clearly part of the title, as the examples show. A location other than the royal necropolis is found on P. Amherst 12 and 13 (Loyalist Instruction). Its colophon states that the text was made in š̌ w'b n pr-imnn, 
"by/for ${ }^{76}$ the scribe, the $w a b$-priest of the temple of Amun”. This colophon is interesting because it shows a connection between a literary text and (a person associated with) a temple, as in CGT 54019. The same applies to the final example belonging to this category, a papyrus from Turin with the Hymn to Hapi. ${ }^{77}$ It also mentions a temple in its colophon, more specifically the mortuary temple of Ramesses IV:

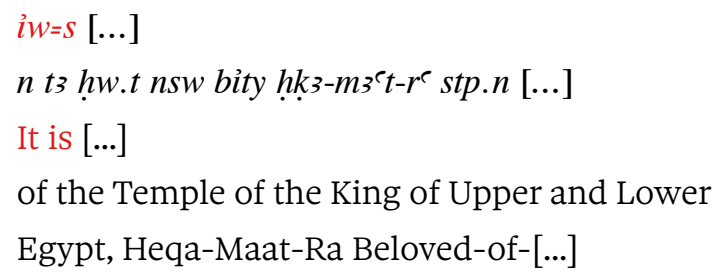

Although the colophon is fragmentary, it seems clear that the $n$, "of", was preceded by the word $s \check{s}$, "scribe", and thus that the location is part of the title.

The association with temples is also apparent in another colophon that cannot be added to one of the three categories due to its fragmentary state. It concerns the colophon of the Blinding of Truth by Falsehood. ${ }^{78}$ At some point it states $i w=f[\ldots]$ hw.t, "while he [...] temple". To whom the $=f$ refers is uncertain, but it probably does not indicate the King, since in such cases $i w=t w$ is used, as we have seen above. A little further on one reads hw.t nsw [...], "the Temple of the King [...]”. The name of the King in question has been lost, but the following lacuna ends with the word imn, "Amun", which may be the final word in the expression $m p r i m n$, "in the domain of Amun", a common addition in the names of royal memorial temples in the Ramesside period. Thus it seems a mortuary temple also features in this colophon.

Taking all of the above into account CGT 54019 may be added to the third category, i.e. the mortuary temple occurs here as part of a title, either of the scribe who copied the text or the person to whom the text was dedicated. This assumption is not only based on statistical grounds, but also on the close parallel with the Turin papyrus containing the Hymn to Hapi. Furthermore, the title "scribe of + mortuary temple" occurs more often. Another example of someone holding this title is Pentaweret who is called a $s \check{s} n$ t3 hw.t nsw bity wsr-m3't-re stp- $n-r^{c} m$ pr imn, thus a scribe of the Ramesseum, the mortuary temple of Ramesses II in Thebes. ${ }^{79}$

\section{Social context}

From circumstantial evidence, including titles of scribes like the ones mentioned above, we know that scriptoria (i.e. places connected to scribal activities) such as the House of Life or the House of Books were associated with temples. ${ }^{80}$ Nevertheless it has been proven difficult to archaeologically identify the structures where these scribal activities took place within the precincts of the temples. Literary material was found at the site of various mortuary temples on the West Bank. In the mud-brick buildings surrounding the Ramesseum fragments of literary papyri were discovered, which point to the existence of an archive or library there. ${ }^{81}$ Furthermore, excavations in the southwestern area of the temple have yielded the remnants of 17 small chambers with a forecourt attached. Many ostraca were found there, including literary ones. The excavators identified this structure as a school ( $\left(. t-s b_{3}\right)$, possibly in combination with a House of Life, ${ }^{82}$ but this has been debated by other scholars, criticising the fact that the identification as a school is solely based on the presence of literary material at the site. ${ }^{83}$ The same applies to the mortuary temple of Amenhotep II. Two literary ostraca (one containing The Teaching of Khety, the other The Teaching of Amenemhat) were discovered near the west wall of the temple in proximity to each other, together with an administrative ostracon and several figured ostraca. For this area it has also been suggested it functioned as a school, but again the evidence is sparse. $^{84}$ An ostracon containing both Khety and Amenemhat was found in the outbuildings belonging to the mortuary temple of Thutmosis III. Recent excavations have revealed yet more literary ostraca at the site, including five copies of Khety. One area in particular yielded a concentration of literary ostraca, but there is not enough evidence to identify it as a place of teaching because of the archaeological context: the area contained spoil heaps from previous excavations. ${ }^{85}$ However, it is likely that some form of training took place in and around temples, if not in the formal setting of a school, then in the form of learning on the job. ${ }^{86}$ For example, the literary ostraca that were found in the mortuary temple of Merenptah often contain texts written in twofold, one by an experienced hand, the other by a less 
skillful one, indicating that one-on-one teaching took place within the temple precinct. ${ }^{87}$ Interesting in this respect is another ostracon with a duplicate text of P. Anastasi V, 10, 3-7 (Miscellanies). It is addressed by the scribe of the temple of Amenhotep (I) Pahemnetjer (š̌ ḥw.t-ntr n pr n imn-ḥtp e-w-s p3-ḥm$n \underline{t} r)$ to his apprentice or assistant $\left(\underline{h} r y-{ }^{c}=f\right)$, the scribe and sem-priest Paimiraperhedj. ${ }^{88}$ The term hry-s may point to an educational context, although this does not necessarily has to be the case. ${ }^{89}$

All in all, the presence of literary material at these

\section{Notes}

${ }^{1}$ I would like to thank Rob Demarée for discussing the hieratic of P. Turin CGT 54019 with me and for his comments on parts of this paper. I am also grateful to Jacobus van Dijk, Olaf Kaper and the anonymous reviewers for their comments and suggestions. Furthermore, I would like to thank Susanne Töpfer for providing me with photographs of the papyrus. I also wish to express my gratitude to the Netherlands Organisation for Scientific Research (NWO), which supported this endeavour (project number 023.008.011).

${ }^{2}$ Roccati, Sapienza egizia, 1994, pp. 79-84.

${ }^{3}$ Roccati, BSFE 148 (2000), pp. 5, 10-12.

${ }^{4}$ Jäger, Altägyptische Berufstypologien, 2004, pp. 5-6.

${ }^{5}$ Roccati, Scavi nel Museo Egizio, 2005. The article was published online at www.archaeogate.org, but is no longer accessible. I thank Rob Demarée for a printed version of the text. P. Sallier II 9,5-11,5, mentioned in the first quotation, corresponds to chapters 22,5-30 of Khety. Roccati mentions the discovery of the papyrus here numbered CGT 54018 in Roccati, in Pennacchietti and Roccati (eds.), Atti della terza giornata di studi, 1984, p. 114. He refers to papyrus CGT 54017 in Roccati, Sapienza egizia, 1994, p. 79; Roccati, in Pennacchietti and Roccati (eds.), Atti della terza giornata di studi, 1984, pp. 113-14.

${ }^{6}$ Rob Demarée, personal comment.

${ }^{7}$ For CGT 54017, see Fischer-Elfert, Die Lehre eines Mannes, 1999, Tafelband, p. X. For CGT 54018, see Frère, RiME 3 (2019), p. 3.

8 Černý, Paper and Books, 1952, pp. 16-17; Parkinson and Quirke, Papyrus, 1995, pp. 16-17.

${ }^{9}$ Other papyri with Khety that contain writing exercises are P. Sallier II and P. Chester Beatty V. For a recent discussion of this phenomenon, see Ragazzoli, Scribes, 2019, pp. 57-62; Jurjens, JARCE 57 (forthcoming). Dates can be found in the margins of P. Bologna 1094, P. Anastasi V and P. Sallier IV; see Hagen, in Dann (ed.), Current Research in Egyptology, 2006, pp. 92-93.

${ }^{10}$ Bierbrier, Who Was Who in Egyptology, 20195 , p. 136; Polis et al., RiME 4 (2020), p. 3.

${ }^{11}$ Quirke, in Loprieno (ed.), Ancient Egyptian Literature, 1996, p. 391.

${ }^{12}$ Because common words like this occur so frequently, sites shows that literary activities were being conducted within the enclosures of mortuary temples, which probably also served as places of training for young scribes. The colophon of CGT 54019 indicates that the papyrus was written by or for a scribe connected to the mortuary temple of Ramesses III. It is likely that the temple was also the place where the text was produced. Thus within the precincts of the temple of Medinet Habu there also existed a place where (literary) texts were copied, as in the other mortuary temples discussed above.

scribes wrote them almost without thinking. Thus, a comparison of the palaeography of such words (e.g. the article $p_{3}$ ) may be useful in identifying scribes: Janssen, JEA 73 (1987), pp. 161-67; van den Berg and Donker van Heel, in Demarée and Egberts (eds.), Deir el-Medina in the Third Millennium AD, 2000.

${ }^{13}$ The dot at the start of the colophon $(3,9)$ is not a verse point, but a meaningless space filler; see Möller, Hieratische Paläographie, II, 1909-1912, No. 119, n. 4.

${ }^{14}$ Motte and Sojic, in Carlig et al. (eds.), Signes dans les textes, 2020, p. 66 (with references).

${ }^{15}$ Foster, in Larson and Teeter (eds.), Gold of Praise, 1999, p. 121.

${ }^{16}$ For the sources, see Jäger, Altägyptische Berufstypologien, 2004, pp. 5-10, I-XCIV; FischerElfert, LingAeg 15 (2007), pp. 308-09; Widmaier, in Ernst et al., Dating Egyptian Literary Texts, 2013, pp. 506-08; Verhoeven, Dipinti von Besuchern des Grabes N13.1, 2020, pp. 123-27, 145-46.

${ }^{17}$ On this method, see Cerquiglini, In Praise of the Variant, 1999, pp. 47-50. Like Cerquiglini, FischerElfert critices Jäger's stemmatic approach in his review of the book: see Fischer-Elfert, LingAeg 15 (2007), p. 309.

${ }^{18}$ Cerquiglini, In Praise of the Variant, 1999. Citations on pp. 77,78 and p. 2.

${ }^{19}$ See for example the recent studies on variants in Ptahhotep and the Miscellanies, respectively: Hagen, Ptahhotep, 2012, pp. 212-39; Ragazzoli, in Gillen (ed.), (Re)productive Traditions, 2017.

${ }^{20}$ Burkard, Textkritische Untersuchungen, 1977, pp. 70, 113-14, 143. See also Jurjens, SAK 50 (forthcoming).

${ }^{21}$ Delnero, JNES 71/2 (2012), pp. 200-02.

${ }^{22}$ Parkinson, Poetry and Culture, 2002, p. 54; Hoch, JSSEA 21/22 (1991-1992), p. 88.

${ }^{23}$ Allen, Middle Egyptian, 2000, §20.16.3.

${ }^{24}$ Jäger, Altägyptische Berufstypologien, 2004, p. 104 (with references).

${ }^{25}$ Gardiner, Egyptian Grammar, $1957^{3}$, §141.

${ }^{26}$ Cf. also Brunner, Die Lehre des Cheti, 1944, p. 44.

${ }^{27}$ Cf. Foster's translation "watch what you say to me!" (Foster, Ancient Egyptian Literature, 2001, p. 40). For the prothetic yod written as $r$, see Erman, Neuaegyptische Grammatik, 1933², §303; Černý and Israelit Groll, A Late Egyptian Grammar, 19934, p. 162. 
The same spelling occurs on O. Turin $57082(r . \underline{d} d . t=k)$, see below, chapter 27,1.

${ }^{28}$ Jäger, Altägyptische Berufstypologien, 2004, p. 105.

${ }^{29} \underline{d} d r$, "gegen jem. (feindlich) sagen”, “über jem. sagen” (Wb V.620.5-6).

30 Černý and Israelit Groll, A Late Egyptian Grammar, $1993^{4}$, p. 162.

${ }^{31}$ Jäger, Altägyptische Berufstypologien, 2004, p. 105.

${ }^{32}$ For some examples, see the Thesaurus Linguae Aegyptiae (after login): http://aaew.bbaw.de/tla/ servlet $/ \mathrm{s} 0 ? \mathrm{f}=0 \& \mathrm{l}=0 \& \mathrm{ff}=2 \& \mathrm{db}=0 \& \mathrm{w} 1=86570 \& 11=0 \& \mathrm{c} 1$ $=0 \& \mathrm{~W} 2=21881 \& 12=0 \& \mathrm{c} 2=0 \& \mathrm{~d} 2=5 \& \mathrm{~d} 1=1 \& \mathrm{~d} 3=1 \& \mathrm{~d} 4=5$.

${ }^{33} \mathrm{~Wb}$ II.300.8.

${ }^{34}$ Parkinson, The Tale of Sinuhe, 1997, p. 281. Others are of the opinion that Khety was a man of distinction, see for example Fischer-Elfert, Lehre eines Mannes, p. 370.

${ }^{35}$ Helck, Die Lehre des dw3-htjj, 1970, p. 122; Jäger, Altägyptische Berufstypologien, 2004, p. LXXVI. Jäger also erroneously places the start of line 5, “[V 1]", after $d \dot{l}=\hat{\imath} r h=k$ instead of before it. For the original hieratic, see Hawkings (ed.), Select Papyri, 1841-1860, pls. CXXI-CXXXII.

${ }^{36} \mathrm{~Wb}$ IV.84.8. See for comparable sentences the Belegstellen of $W b$ II.445.13. For a discussion of the other sources, see Jäger, Altägyptische Berufstypologien, 2004, p. 107.

${ }^{37}$ Jäger, Altägyptische Berufstypologien, 2004, pp. 107-08.

${ }^{38} \mathrm{~Wb}$ I.215.10.

${ }^{39} \mathrm{~Wb}$ V.335.5.

${ }^{40}$ P. Anastasi VII, 5, 2 (Hawkings [ed.], Select Papyri, 1841-1860, pl. 132).

${ }^{41}$ P. Sallier II, 9, 7 (chapter 24,1).

42 Posener, RdE 11 (1957), pp. 119-37; van Dijk, in Berger et al. (eds.), Hommages à Jean Leclant, 1994.

${ }^{43}$ Allen, Middle Egyptian, 2000, §19.11.1 and the last example on p. 256.

${ }^{44} \mathrm{~Wb}$ I.451.3.

${ }^{45}$ For a discussion, see Jäger, Altägyptische Berufstypologien, 2004, pp. 108-09.

${ }^{46} \mathrm{~Wb}$ II.387.22.

${ }^{47}$ Jäger, Altägyptische Berufstypologien, 2004, p. 111.

${ }^{48}$ For h $h_{3}$, compare column 2, line 9. See also Möller, Hieratische Paläographie, II, 1909-1912, No. 227.

${ }^{49}$ Jäger, Altägyptische Berufstypologien, 2004, p. 111.

${ }^{50}$ Jäger, Altägyptische Berufstypologien, 2004, p. 112.

${ }^{51}$ Jäger, Altägyptische Berufstypologien, 2004, p. 114.

${ }^{52}$ Erman, Neuaegyptische Grammatik, 1933², §606.

${ }^{53}$ Gardiner, Egyptian Grammar, 195733 §200.2; Wb I.450.11.

${ }^{54}$ Brunner, Die Lehre des Cheti, 1944, p. 47. Helck and Jäger emend to $\underline{d} d \boldsymbol{m j} \underline{d} d . t=f$ (Helck, Die Lehre des $d w_{3}-$ htjj, 1970, p. 137; Jäger, Altägyptische Berufstypologien, 2004, p. 116).

${ }^{55}$ Erman, Neuaegyptische Grammatik, 1933², §91.

${ }^{56}$ O. Kat. Nr. 6, to be published by Matthias Müller (cf. Müller, in Toivari-Viitala et al. [eds.], Deir el-Medina Studies, 2014).

${ }^{57}$ Jäger, Altägyptische Berufstypologien, 2004, p. 117.

${ }^{58}$ Delnero, JNES 71/2 (2012), p. 203.

${ }^{59}$ Fischer-Elfert, Die Lehre eines Mannes, 1999, pp. 373-74.

${ }^{60}$ The lacuna between $s$ and $\underline{d} 3 m$. $w$ would seem to be too small to contain the indirect genitive $n$.

${ }^{61}$ Allen, Middle Egyptian, 2000, §8.14.

${ }^{62}$ E.g. Simpson, The Literature of Ancient Egypt, 1973, p. 336; Parkinson, The Tale of Sinuhe, 1997, p. 281; Quirke, Egyptian Literature 1800 BC, 2004, p. 126.

${ }^{63}$ Jäger, Altägyptische Berufstypologien, 2004, p. 124.

${ }^{64}$ Helck, Die Lehre des dw3-htjj, 1970, p. 144.

${ }^{65}$ Cf. Wb I.210.17; Wb I.211.13; Wb I.209.13-14.

${ }^{66}$ Roccati, in Pennacchietti and Roccati (eds.), Atti della terza giornata di studi, 1984, pp. 113-15.

${ }^{67}$ Literally, "it is that it comes" (Allen, Middle Egyptian, 2000, §25.3.5).

${ }^{68}$ Luiselli, in Bickel and Loprieno (eds.), Basel Egyptology Prize 1, 2003, pp. 347, 354; Lenzo Marchese, BIFAO 104/1 (2004), pp. 364-66.

${ }^{69}$ The same "mistake" occurs in P. Anastasi III, 4,11 en 7,10 (Gardiner, Late-Egyptian Miscellanies, 1937, pp. 25,29$)$. If the reading order is adhered to, it follows that the scribe omitted the $n$ of in (so also Caminos, Late-Egyptian Miscellanies, 1954, p. 88). Alternatively, it may be that the scribe first wrote in, then put the sign for $k 3$ in the free space above the $n$, and then continued the line. If so, the genitival adjective was omitted: in $k 3<n>$. For the omission of the genitival adjective after in $k_{3}$, see for example P. Sallier II, 3,8 and 11,5.

${ }^{70}$ The full name of the mortuary temple was hww.t wsrm3`.t-r mry-imn hnmm.t-nhh m $m$ pr imn hr imnt.t-wss.t (Haring, Divine Households, 1997, p. 395). On the names of royal mortuary temples in general, see Haring, Divine Households, 1997, pp. 19-27; Ullmann, Die Häuser der Millionen von Jahren, 2002, pp. 639-51.

${ }^{71}$ P. Anastasi VII, 7, 4-6 (Hawkings [ed.], Select Papyri, 1841-1860, pl. 134).

${ }^{72}$ P. Sallier I, 3, 4-5 (Gardiner, Late-Egyptian Miscellanies, 1937, p. 79): "Beginning of the instruction of letterwriting made by the scribe Pentawer in year 10, fourth month of Inundation, day 7 , when One was in ( $i w=t w$ m) House-of-Ramesses-Meryamun-l.p.h.,-the-GreatKa-of-Pre-Harakhti”. As regards literary texts, all other examples of this phrase are actually found on papyri containing Miscellanies and all mention Piramesse as the location of the King: P. Sallier IV (jotting on the verso), P. Anastasi IV (jotting on the verso), P. Anastasi III A (jotting on the verso) and P. Anastasi VI, 4-5 (in an introductory formula). See also Gardiner, JEA 5/3 (1918); Hagen, in van Dijk (ed.), Another Mouthful of Dust, 2016, pp. 177-78.

${ }^{73}$ For examples, see Hagen, in van Dijk (ed.), Another Mouthful of Dust, 2016, pp. 164-77.

${ }^{74}$ P. Chester Beatty I, 16, 8 (Gardiner, Late-Egyptian Stories, 1932, p. 60). The word $t b$ is difficult to explain. Various suggestions have been made regarding its translation, see Verhoeven, in Schade-Busch (ed.), Wege öffnen, 1996, pp. 351-52; Broze, Mythe et roman en Égypte ancienne, 1996, p. 124.

${ }^{75} \mathrm{O}$. Michaelides 20bis (Goedicke and Wente, Ostraka Michaelides, 1962, pls. VI-VII); O. BM EA 29549 (Demarée, Ramesside Ostraca, 2002, pl. 77); O. Turin 57431 (López, Ostraca ieratici, 1978-1984, pls. 138, 138a); O. hier. Straßburg H. 108 (Fischer-Elfert, GM 176 [2000], p. 112); O. Turin 57319 + O. DeM 1635 (López, 
Ostraca ieratici, 1978-1984, pls. 100, 100a; Posener, Catalogue, III, 1977-1980, pls. 63, 63a). On the term "Place of Truth", see Haring, in Verschoor et al. (eds.), Imaging and Imagining the Memphite Necropolis, 2017.

${ }^{76}$ See Lenzo Marchese, BIFAO, 104/1 (2004), p. 363.

${ }^{77}$ Papyrus Turin Cat. $1968+1890+1878$ ro. and CGT 54016 according to Dirk van der Plas (van der Plas, L'hymne à la crue du Nil, 1986, pp. 4, 148), but the fragment actually belongs to CGT 54018 (Frère, RiME 3 [2019], p. 43).

${ }^{78}$ P. Chester Beatty II, 11, 5-6 (Gardiner, Late-Egyptian Stories, 1932, p. 36).

${ }^{79}$ P. Chester Beatty V, verso 2, 2-3 (Gardiner, Hieratic Papyri in the British Museum, 1935, pl. 27). For scribes attached to mortuary temples in general, see Haring, Divine Households, 1997.

${ }^{80}$ For a discussion, see Hagen, in Ryholt and Barjamovic (eds.), Libraries Before Alexandria, 2019.

${ }^{81}$ Hagen, in Ryholt and Barjamovic (eds.), Libraries Before Alexandria, 2019, pp. 251-52.

${ }^{82}$ Leblanc, Memnonia 15 (2004); Barbotin, Memnonia 24 (2013).

${ }^{83}$ Hagen, Ostraca from the Temple of Millions of Years, 2021, p. 7. Hagen, Ptahhotep, 2012, pp. 78-79, 244; Hagen, in Ryholt and Barjamovic (eds.), Libraries Before Alexandria, 2019, pp. 257-58; Quirke, in Loprieno (ed.), Ancient Egyptian Literature, 1996, pp. 393-94.

${ }^{84}$ Khety: Ostr. CRB/97/NE/26 (Demichelis, Memnonia 14 [2003]); Amenemhat: CRB/ 96/SE/32 (Sesana and Nelson, Memnonia 9 [1998]). For the suggested use of the location as a school, see Petrie, Six Temples at Thebes, 1896, p. 4; Sesana and Nelson, Memnonia 9 (1998), p. 192; but cf. Hagen, Ptahhotep, 2012, p. 78.

${ }^{85}$ O. CGC 25217, see Daressy, Ostraca, 1901, p. 47, pl. 42. The recent finds are O. T3.L17-21, see Hagen, Ostraca from the Temple of Millions of Years, 2021, pp. 43-44, pls. 66-68, 79-80, 89. For the archaeological context, see Hagen, Ostraca from the Temple of Millions of Years, 2021, p. 12.

${ }^{86}$ Ragazzoli, BSFE 201 (2019), p. 73. Cf. also Abrahami and Coulon, in Pantalacci (ed.), La Lettre d'archive, 2008, pp. 3-7.

${ }^{87}$ Müller, in Toivari-Viitala et al. (eds.), Deir el-Medina Studies, 2014, pp. 146, 150.

88 Černý and Gardiner, Hieratic Ostraca, 1957, pl. 10,3. Cf. also O. BM EA 65599/65600 (Demarée, Ramesside Ostraca, 2002, p. 39, pls. 163-64), which contains an excerpt from the Prophecy of Neferti, followed by a colophon featuring a priest $(h m-n t r)$. The ostracon also contains writing exercises and a student's exercise in numerals.

${ }^{89}$ Ragazzoli, Scribes, 2019, pp. 123-31. Ragazzoli convincingly argues that the term is not only used for apprentice scribes, but also for professional scribes, probably at the start of their career, who had a superior or elder above them. The term thus designates an hierarchical relationship in a fairly wide range of situations.

\section{Bibliography}

Abrahami, P. and L. Coulon, “De l'usage et de l'archivage des tablettes cunéiformes d'Amarna”, in: L. Pantalacci (ed.), La Lettre d'archive. Communication administrative et personnelle dans l'Antiquité proche-orientale et égyptienne. Actes du colloque de l'université de Lyon II, 9-10 juillet 2004 (BiGen 32), Cairo 2008, pp. 1-26.

Allen, J., Middle Egyptian: An Introduction to the Language and Culture of Hieroglyphs, Cambridge 2000.

Barbotin, C., "Les ostraca hiératiques de l'école du Ramesseum”, Memnonia 24 (2013), pp. 73-79.

Bierbrier, M., Who Was Who in Egyptology, London $2019^{5}$.

Broze, M., Mythe et roman en Égypte ancienne : les aventures d'Horus et Seth dans le papyrus Chester Beatty I (OLA 76), Leuven 1996.

Brunner, H., Die Lehre des Cheti, Sohnes des Duauf (ÄgForsch 13), Glückstadt 1944.

Burkard, G., Textkritische Untersuchungen zu ägyptischen Weisheitslehren des Alten und Mittleren Reiches (̈̈A 34), Wiesbaden 1977.

Caminos, R., Late-Egyptian Miscellanies (BEStud 1), London 1954.

Černý, J., Paper and Books in Ancient Egypt: An Inaugural Lecture Delivered at University College London, 29 May 1947, London 1952.

Černý, J. and A. Gardiner, Hieratic Ostraca, I, Oxford 1957.

Černý, J. and S. Israelit Groll, A Late Egyptian Grammar, Roma $1993^{4}$.

Cerquiglini, B., In Praise of the Variant: A Critical History of Philology, Baltimore 1999.

Daressy, G., Ostraca (CGC nos 25001-25385), Le Caire 1901.

Delnero, P., "Memorization and the Transmission of Sumerian Literary Compositions”, JNES 71/2 (2012), pp. 189-208.

Demarée, R., Ramesside ostraca, London 2002.

Demichelis, S., "Deux ostraca hiératiques découverts au Nord-Ouest du complexe de la 'Chapelle de la reine blanche”, Memnonia 14 (2003), pp. 87-91.

Erman, A., Neuaegyptische Grammatik, Leipzig $1933^{2}$.

Fischer-Elfert, H.-W., Die Lehre eines Mannes für seinen Sohn: eine Etappe auf dem "Gottesweg" des loyalen und solidarischen Beamten des Mittleren Reiches (ÄA 60), Wiesbaden 1999.

Fischer-Elfert, H.-W., “Ostrakon hier. Straßburg H. 108: Brouillon eines Stiftungsvermerks oder Teil eines literarischen Kolophons des Schreibers Pasched", GM 176 (2000), pp. 111-12.

Fischer-Elfert, H-W., "Review of Jäger, S., Altägyptische Berufstypologien (LingAeg Studia Monographica 4), Göttingen 2004”, LingAeg 15 (2007), pp. 307-14.

Foster, J., "Some Comments on the Instruction for Little Pepi on His Way to School (The Satire on the Trades)", in: J. Larson and E. Teeter (eds.), Gold of Praise: Studies on Ancient Egypt in Honor of Edward F. Wente, Chicago 1999, pp. 121-29.

Foster, J., Ancient Egyptian Literature: An Anthology, Austin 2001.

Frère, M., "La nomination du vizir Ouseramon d'après le papyrus Turin Cat. 1878 vo”, RiME 3 (2019).

Gardiner, A., "The Delta Residence of the Ramessides", JEA 5/3 (1918), pp. 179-200. 
Gardiner, A., Late-Egyptian Stories (BiAeg 1), Brussels 1932.

Gardiner, A., Hieratic Papyri in the British Museum: Third Series: Chester Beatty Gift, London 1935.

Gardiner, A., Late-Egyptian Miscellanies (BiAeg 7), Brussels 1937.

Gardiner, A., Egyptian Grammar: Being an Introduction to the Study of Hieroglyphs, Oxford $1957^{3}$.

Goedicke, H. and E. Wente, Ostraka Michaelides, Wiesbaden 1962.

Goelet, O., "Writing Ramesside Hieratic: What the Late Egyptian Miscellanies Tell Us About Scribal Education”, in: S. D'Auria (ed.), Servant of Mut: Studies in Honor of Richard A. Fazzini, Leiden 2008, pp. 102-10.

Hagen, F., "Literature, Transmission, and the Late Egyptian Miscellanies”, in: R.J. Dann (ed.), Current Research in Egyptology 2004: Proceedings of the Fifth Annual Symposium Which Took Place at the University of Durham January 2004, Oxford 2006, pp. 84-99.

Hagen, F., An Ancient Egyptian Literary Text in Context: The Instruction of Ptahhotep (OLA 218), Leuven 2012.

Hagen, F., "On Some Movements of the Royal Court in New Kingdom Egypt”, in: J. van Dijk (ed.), Another Mouthful of Dust: Egyptological Studies in Honour of Geoffrey Thorndike Martin (OLA 246), Leuven 2016, pp. 155-81.

Hagen, F., "Libraries in Ancient Egypt, c.1600-800 BCE", in: K. Ryholt and G. Barjamovic (eds.), Libraries Before Alexandria: Ancient Near Eastern Traditions, Oxford 2019, pp. 244-318.

Hagen, F., Ostraca from the Temple of Millions of Years of Thutmose III (Culture and History of the Ancient Near East 120), Leiden 2021.

Haring, B., Divine Households: Administrative and Economic Aspects of the New Kingdom Royal Memorial Temples in Western Thebes (EgUit 12), Leiden 1997.

Haring, B., "Saqqara: A Place of Truth?”, in: V. Verschoor, A. Stuart and C. Demarée (eds.), Imaging and Imagining the Memphite Necropolis: Liber Amicorum René van Walsem (EgUit 30), Leiden 2017, pp. 147-53.

Hawkings, E. (ed.), Select Papyri in the Hieratic Character from the Collections of the British Museum, London 1841-1860.

Helck, W., Die Lehre des $d w 3$-hntjj (KÄT 3), Wiesbaden 1970.

Hoch, J., "The Teaching of Dua-Kheti: A New Look at the Satire of the Trades", JSSEA 21/22 (1991-1992), pp. 88-100.

Jäger, S., Altägyptische Berufstypologien (LingAeg Studia Monographica 4), Göttingen 2004.

Janssen, J., “On Style in Egyptian Handwriting”, JEA 73 (1987), pp. 161-67.

Jurjens, J., "The Educational Context of a Literary Text: Some Notes on Writing Exercises and Drawings as Found on Material Containing The Teaching of Khety", JARCE 57 (forthcoming).

Jurjens. J., "Corrections on Ostraca: A Look into an Ancient Egyptian Scribal Practice”, SAK 50 (forthcoming).

Leblanc, C., "L'école du temple (ât-Sebaït) et le per-ankh (maison de vie) : à propos de récentes découvertes effectuées dans le contexte du Ramesseum", Memnonia 15 (2004), pp. 93-101.

Lenzo Marchese, G., "Les colophons dans la littérature égyptienne", BIFAO 104/1 (2004), pp. 359-76.

López, J., Ostraca ieratici (CMT. Serie Seconda - Collezioni 3), Milano 1978-1984.

Luiselli, M., "The Colophons as an Indication of the Attitudes towards the Literary Tradition in Egypt and Mesopotamia”, in: S. Bickel and A. Loprieno (eds.), Basel Egyptology Prize 1: Junior Research in Egyptian History, Archaeology, and Philology, Basel 2003, pp. 343-60.

Möller, G., Hieratische Paläographie. Die ägyptische Buchschrift in ihrer Entwicklung von der fünften Dynastie bis zur römischen Kaiserzeit, I-III, Leipzig 1909-1912.

Motte, A. and N. Sojic, "Paratextual Signs in the New Kingdom Medico-Magical Texts”, in: N. Carlig, G. Lescuyer, A. Motte and Nathalie Sojic (eds.), Signes dans les textes: continuités et ruptures des pratiques scribales en Égypte pharaonique, gréco-romaine et byzantine. Actes du colloque international de Liège (2-4 juin 2016) (Papyrologica Leodiensia 9), Liège 2020.

Müller, M., "Ostraka aus dem Totentempel des Merenptah in Theben”, in: J. Toivari-Viitala, T. Vartiainen and S. Uvanto (eds.), Deir el-Medina Studies: Helsinki, June 24-26, 2009 Proceedings, Vantaa 2014, pp. 144-53.

Parkinson, R. and S. Quirke, Papyrus, London 1995.

Parkinson, R., The Tale of Sinuhe and Other Ancient Egyptian Poems, 1940-1640 BC, Oxford 1997.

Parkinson, R., Poetry and Culture in Middle Kingdom Egypt: A Dark Side to Perfection, London 2002.

Petrie, W., Six Temples at Thebes: 1896, London 1896.

Polis, S., K. Gabler, C. Greco, E. Hertel, A. Loprieno, M. Müller, R. Pietri, N. Sojic, S. Töpfer and S. Unter, "Crossing Boundaries: Understanding Complex Scribal Practices in Ancient Egypt (With a 2019 Progress Report)," RiME 4 (2020), pp. 1-15.

Posener, G., "Le conte de Neferkarê et du général Siséné (recherches littéraires, VI)”, RdE 11 (1957), pp. 119-37.

Posener, G., Catalogue des ostraca hiératiques littéraires de Deir el Médineh III: Nos 1267 à 1675 (DFIFAO 20), Le Caire 1977-1980.

Quirke, S., “Archive”, in: A. Loprieno (ed.), Ancient Egyptian Literature: History and Forms, Leiden 1996, pp. 379-401.

Quirke, S., Egyptian Literature 1800 BC: Questions and Readings (GH Egyptology 2), London 2004.

Ragazzoli, C., "Beyond Authors and Copyists: The Role of Variation in Ancient Egyptian and New Kingdom Literary Production”, in: T. Gillen (ed.), (Re) productive Traditions in Ancient Egypt: Proceedings of the Conference Held at the University of Liège, 6th-8th February 2013, Liège 2017, pp. 95-126.

Ragazzoli, C., Scribes : les artisans du texte en Égypte ancienne, Paris 2019.

Ragazzoli, C., "La littérature de scribe au Nouvel Empire ou pourquoi les miscellanées ne sont pas des textes scolaires”, BSFE 201 (2019), pp. 44-78.

Roccati, A., “Conservatività dell'egiziano”, in: F. Pennacchietti and A. Roccati (eds.), Atti della terza giornata di studi camito-semitici e indoeuropei, Roma 1984, pp. 107-15.

Roccati, A., Sapienza egizia. La letteratura educativa in Egitto durante il II millennio a.C., Brescia 1994. 
Roccati, A., "Réflexions sur la Satire des Métiers”, BSFE 148 (2000), pp. 5-17.

Roccati, A., "Scavi nel Museo Egizio di Torino (VII. TRA I PAPIRI TORINESI)”, Archaeogate (2005) (published online on 16/06/2005, but no longer accessible).

Sesana, A. and M. Nelson, "Exercices d'élèves-artisans découverts au sud-ouest du temple de " millions d'années » d’Amenophis II”, Memnonia 9 (1998), pp. 191-99.

Simpson, W., The Literature of Ancient Egypt: An Anthology of Stories, Instructions, and Poetry, London 1973.

Tacke, N., Verspunkte als Gliederungsmittel in ramessidischen Schülerhandschriften (SAGA 22), Heidelberg 2001.

Ullmann, M., Die Häuser der Millionen von Jahren: eine Untersuchung zu Königskult und Tempeltypologie in

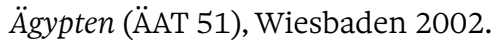

van den Berg, H. and K. Donker van Heel, “A Scribe's Cache from the Valley of Queens? The Palaeography of Documents from Deir el-Medina: Some Remarks", in: R.J. Demarée and A. Egberts (eds.), Deir el-Medina in the Third Millennium AD: A Tribute to Jac. J. Janssen (EgUit 14), Leiden 2000, pp. 9-49.

van Dijk, J., “The Nocturnal Wanderings of King Neferkarē", in: C. Berger, G. Clerc and N. Grimal (eds.), Hommages à Jean Leclant, IV, Cairo 1994, pp. 387-93.

van der Plas, D., L’hymne à la crue du Nil (EgUit 4), Leiden 1986.

Verhoeven, U., Dipinti von Besuchern des Grabes N13.1 in Assiut (The Asyut Project 15), Wiesbaden 2020.

Verhoeven, U., “Ein historischer „Sitz im Leben“ für die Erzählung von Horus und Seth des Papyrus Chester Beatty I", in: M. Schade-Busch (ed.), Wege öffnen: Festschrift für Rolf Gundlach zum 65. Geburtstag, Wiesbaden 1996, pp. 347-63.

Widmaier, K., “Die Lehre des Cheti und ihre Kontexte: Zu Berufen und Berufsbildern im Neuen Reich", in: G. Moers, K. Widmaier, A. Giewekemeyer, Arndt Lümers, and R. Ernst (eds.), Dating Egyptian Literary Texts (Lingua Aegyptia Studia Monographica 11), Hamburg 2013, pp. 483-557. 